GEOLOGY OF THE EUREKA CREEK AREA, EAST-CENTRAL ALASKA RANGE

by

James H. Stout

GEOLOGIC REPORT 46

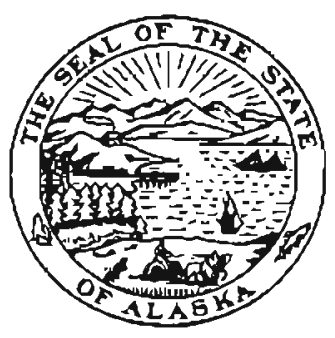




\section{STATE OF ALASKA}

Jay S. Hammond, Governor

Guy R. Martin, Commissioner, Dept. of Natural Resources

Ro6s G. Schaff, State Geologist

For sale by Alaska Division of Geological and Geophysical Surveys, P.0. Box 80007, College, 89701; 323 E. fth Ave, Anchorage. 99601: P.O. Box 2438, Kelchikan, 98901: and Pouch M. Juneau, 99811 . 


\section{CONTENTS}

\begin{tabular}{|c|c|c|c|}
\hline & Page & & Page \\
\hline (2, & 1 & Boulder Creek Volcanics................................... & 14 \\
\hline 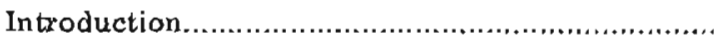 & 1 & Jura-Cretaceous metamorphic rocks.................. & 17 \\
\hline 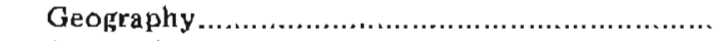 & 1 & 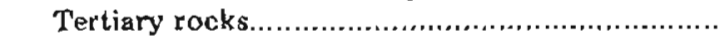 & 19 \\
\hline 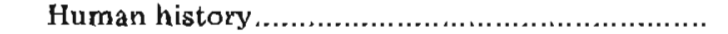 & 2 & 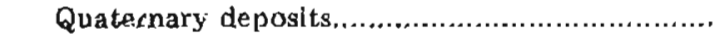 & 20 \\
\hline Previous investigations........................ & 2 & 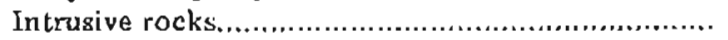 & 21 \\
\hline 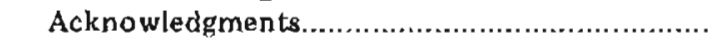 & 2 & Intrusive rocks south of the Broxson Gulch & \\
\hline 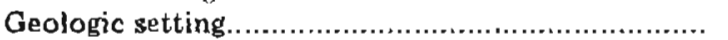 & 3 & 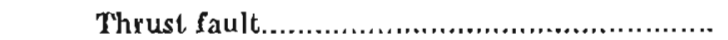 & $2 \mathfrak{l}$ \\
\hline 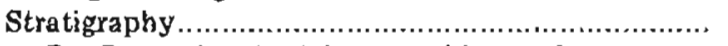 & 4 & Intrusive rocks north of the Broxson Gulch & \\
\hline Pre-Pennsylvanian(!) greenschists and & & 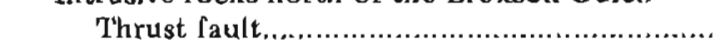 & 23 \\
\hline 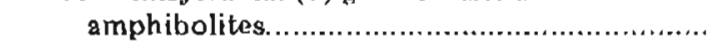 & 4 & 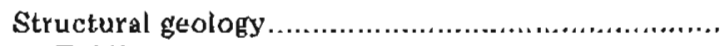 & 26 \\
\hline 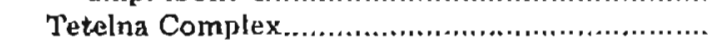 & 6 & Folding........................ & 26 \\
\hline Mankomen Group. & 8 & Faulting................. & 28 \\
\hline 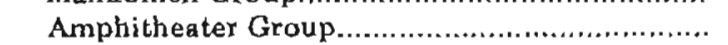 & 10 & Joints...................... & 30 \\
\hline Paxon Mountain basalt.... & 10 & 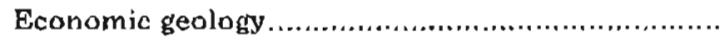 & 30 \\
\hline Tangle Lakes Formation................................. & 12 & 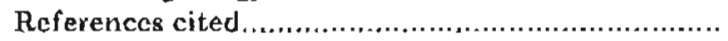 & 31 \\
\hline
\end{tabular}

\section{ILLUSTRATIONS}

PLATE 1. Geologic map of the Eureka Creek area, east-central Naska Range,.................................... In pocket

FIGURE 1. South flank of the central Naska Range as viewed from the Amphitheater Mountains...................

2. Generalized geologic map of the central and east-central Alaska Range...................................... 3

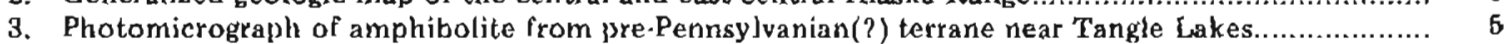

4. Photomicrograph of highly deformed andesite at the base of the Broxson Gulch Thrust lault.......... 7

5. Summary of straligraphy within the Pennsylvanian and Permian Tetelna Complex............................ 8

6. Summary of stratigraphy within the Permian Mandromen Group ............................................. 9

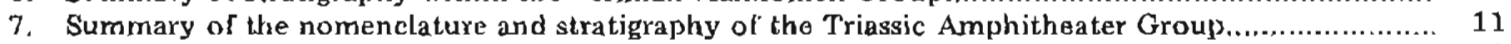

8. Pholomicrograph of amygdaloidal basalt within the Paxson Mountain Basalt near Rainy Creek........ 12

9. Photomicrograph of volcanic agglomerate from the Tang\}e Lakes Formation............................... 13

10. Photomicrograph of fine-grained andesile flow showing small laths of plagioclase (PL) with swallowlall morphology ....................................................................................... 14

11. End view of welt developed pillows in andesite of the Tangle Lakes Formation................................

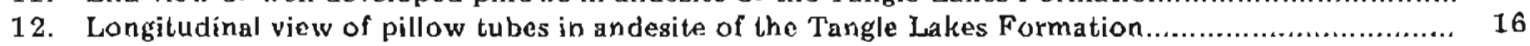

13. Typical layering of amygdaloiklal flows within the Boulder Creek Volcanics............................. 17

14. Anygdules alligned parallel to primary compositional layering to the Boulder Creek Volcanics........ 17

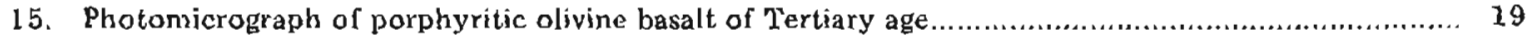

16. Dunite conglomerate in outcrop east of Broxson Ciulch .................................................. 19

17. Photomicrograph of coarse sandstone interbedded with dunite conglomerate near Broxson Gulch.... 20

18. Typical outcrop surface of dunite and peridolite within the Fish Lake Complex........................... 22

19. Photomicrograph of tremotite marble formed at the margin of intrusive gabbro 5 miles north of Sevenmile Lake.

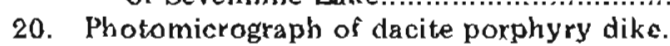

21. Intrusive breccia formed by country rock of pelitic ochist contained within quartz moneonite.......

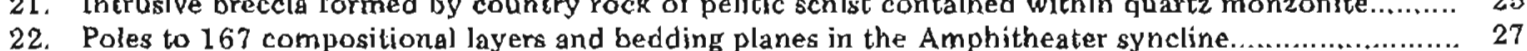

23. The Broxson Gulch Thrust Fault $(F)$ as viewed from the Richardson High way near milepost $218 \ldots \ldots .28$

24. A near-horizontal thrust fault near Broxson Gulch which places Jura-Cretaceous phyllite (on right) on top of Permian volcanics (on left). 


\section{CONTENTS}

\section{TABLES}

TABLE 1. Stratigraphic summary of layered rocks in the Eureka Creek area...................................................5

2. Modes of repregentative specimens from Pre-Pennaylvanian(?) greenschists and amphibolites

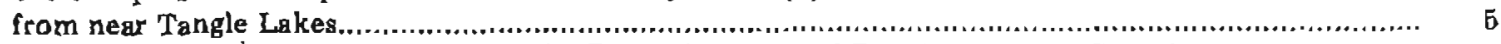

3. Modes of representative specimens from the Pennsylvanian and Permian Tetelna Complex..................... 7

4. Modes of repregentative specimens from the Amphitheater Group.....................................................

5. Modes of representative phylites and greenschists from the Maclaren metamorphic belt...................... 18

6. Modes of representative mafic and ultramafic intrusive rocks from the Amphitheater Mountains and vicinity.............................................................................................

7. Modes of representative felsic intrusive rocks north of and within the Broxson Gulch

8. Modes of representative mafic and ultramafic intrusive rocks north of and within the Broxson Gulch Thrust fault..... 


\title{
GEOLOGY OF THE EUREKA CREEK AREA, EAST.CENTRAL ALASKA RANGE
}

\author{
By dames H Stout 1
}

\section{ABSTRACT}

Geologic investigalions in portions of the Mt. Hayes A.4, A-5, B-4, and B-5 quadrangles near Eureka Creek reveal a folded and fuulted succession of predominantly volcanic rocks yanging in age from pre-Pennsylvanian(?) to Late Triassic. Pre-Pennsylvanian amphibolites and greenschists exposed south of the Denali Highway are unconformably overlain by the Pennsylvanian and Permian Tetelna Complex, a sequence of subaerial dacitic to andesitic volcanics and volcaniclastic sediments. These. rocks apparently grade into the predominantly marine limestones and stales of the Mankomen Group exposed at Rainy and Eureka Creeks. Collectively, the Upper Paleozoic rocks are approximately 15,000 leet thick.

A very thick succession of basaltic to andesitic nows and related volcaniclastics of the Amphitheater Group unconformably(?) overlie the uppermost Permian straka. Three formations are recognized, The Paxson Mountain Basalt consists of approximately 9500 feet to subaerial basalts recrystallized to greenstone. The Tangle Lakes Formation consists of approximately 13,000 feet of andesite flows, volcanic luffs, and tuffaceous sediments. Its marine environment of deposition is evidenced by thin tuffaceous limestones liat Incally contain bate Triassic pelecypods, and by abundant pillows in the flows. The Boulder Creek Volcanics consist of at least 18,500 feet of slightly recrystallized gray-green basalt interlayered with distinctive amygdaloidal zones. Coliectively, the ihree formations comprise over 40,000 feet of predominantly volcanic rocks accumulated dur ing Triassic time. These rocks form part of a belt along' the south flank of the Alaska Range that correlates in age and lithology with similar sequences in the Wrangell Mnuntains, at Kluane Lake (YT), and on Vancouver Island.

This thick sequence is separated in both time and space from Late Jurassic to Cretaceous argillaceous sediments and volcanics which are correlative with the Gravina-Nutzotin belt elsewhere in Alaska. These racks in the Eureka Creek area have been regionally metamorphosed to the sillimanite zone in the Late Cretaceous and are part of the Maclaren metamorphic belt. The contact botween the relatively unmetamorphosed pre-Jurassic terrane and the highly metamorphosed younger sediments is the Broxson Gulch Thrust fault, a major structural break that extends for a minimum distance of 50 miles along the south Tank of the Alaska Range. Stratigraphic and structural arguments suggest that the contact is a faulted unconformity.

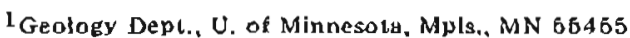

Dunile and other ultramatic intrusives of probable Tertiary age along the Broxson Gulch Thrust fault and along the Denali Fault east of the Delta River suggest that faulting and intrusions were broadly contemporaneous-perhaps as recently as post-Late Oligocene. Fossiliferous Late Oligocene(?) sandstones and conglomerate are highly deformed along the Broxson Gulch Thrust fault, and younger conglomerates contain abundant clasts from the ultramafic rocks.

\section{INTRODUCTION}

\section{GEOGRAPHY}

The Eureka Creek area covers approximately 500 square miles between the Denali Kighway and the south flank of the central Alaska Range. The area is bounded on the east by the Richardson Highway and on the west by the Maclaren River. It encompasses major portions of the $\mathrm{Mt}$. Hayes A-4, A-5, B-A, and B-5 30-minute quadrangles.

The Lopography is varied. Terrane north of Eureka Creek is characterized by steep unvegetated ridges separated by active valley glaciers. The most notable of these is the Maclaren Glacier, the East Maclaren Glacier, asd several smalter, unnamed glaciers at the headwaters of Eureka Creek. Each of these produces substantial runoff during the summer months and renders the glacial streams impassable by foot. Drainage from the East Maclaren Giacier bifurcates into the east-flowing Eureka Creek and into the west-flowing Maclaren River (East Fork). The latter finds egress to the Gulf of Alaska by way of the Susitna River, whereas the former joins the Delta River, which flows north to the Tanana and Yukon Rivers and eventually to the Bering Sea. The lofty peaks that form the crest of the Alaska Range north of the map area attain elevations of 9,000 to 10,000 feet (fig. 1 ).

In contrast, the topography south of Eureka Creek is more subdued. The Amphitheater Mountains, con. tained entirely within the map area, are characterized by less severely dissected ridges flanked by broadly sloping talus and glacial deposits. Maximum elevations are near 6,000 feet. There is no active glaciation. However, the evidence for previous glaciation is strikingly preserved in the several U-shaped watergaps that extend in a north-south direction across the regional trend of 


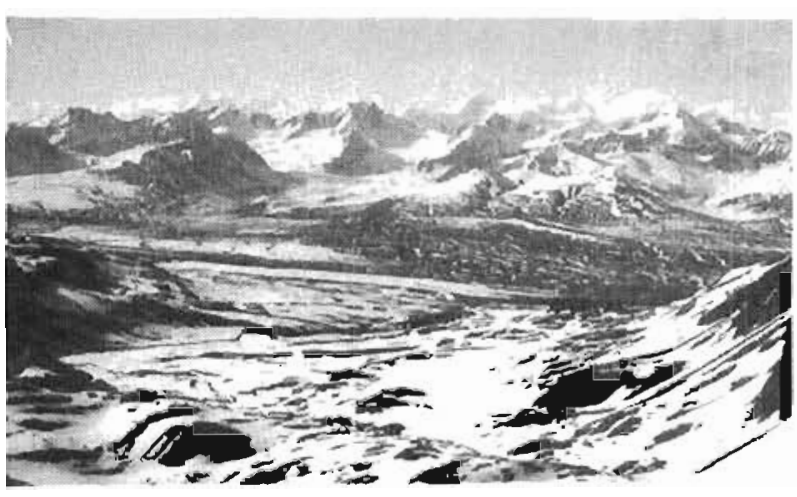

Figure 1. South flank of the central Alaska Range as viewed from the Amphithenter Mountains. Eureka Creek and the West Fork Glacier are in the middle ground. Photo looking north.

the Amphitheater Mountins. Most notable of these are Landmark Gap and the Delta River valley. Small glacial cirques are common above 4,000 teet.

South of the Amphitheater Mountains and the Denali Highway, the topography is genlle, consisting pre. dominantly of glacial deposits that mantle all but a few isolated bedrock lacalities. A notable exception is Paxson Mountain, which rises to 5,500 feel in the southeastern corner of the map area (pl. 1).

Vegetation in the area is sparse. Conifers are present at elevations below 3,000 feel and are abundant only along the Delta River and Rainy Creek. Scaltered brush exists locally up to 4,000 feet. At higher elevalions, the low.lying tundra vegetation is predominant.

Convenient access to the irarginal portions of the map area is achieved by automobile on the Richardson and Denali Highways. These roads cross the Maclaren River and the Delta River, both of which may be navigated by riverboat. Fixed-wing support, on wheels or florts, is available at Summit Lake and Susitna River. Namerous lakes are accessible by flout plane south of Eureka Creek, but none are large enough for safe operation further north. A landing strip at Broxson Gulch provides fixed-wing access north of Eureka Creek-as do several oulwash plains at the base of the Maclaren and East Maclaren Glaciers. The entire area is accessible by fool.

\section{HUMIAN HIS'TORY}

Evidence of early man in the Eureka Creek area is scanty. but apparently occasional bands of lindians frequented the Landmark Gap area in the Amphitheater Mountains in search of rock suitable for tool working. Several sites al Landniark Gap and Tangle Lakes have been identified by abumdant chips of siliceous tuff which outcrops locally. These are presently under investigation by an archeological group from Alaska Melhodist University.

More recently, the quest lor gold and copper has attracted prosuectors and mining companies al varıous times to this otherwisc unimhabitated area. Gold placers at Broxson Ciulch and Rainy Creek (Brooks, 1918; Martin, 1920) were worked successfully as early as 1903. The operation at Broxson Gulch has been active in recent years. Numerous clains cxist elsewhere, notably on Rainy Creek, where copper and nickel sulfides are present in a gabbro porphyry, and in the eastern part of the Amphitheater Mounlains, where copper-sulfide bearing quartz veins and joint surfaces are common. Other than those employed by occasional mining interesis, the only inhabitants are seasonal residents at Tangle Lakes and Maclaren River.

\section{PREVIOUS INVESTIGATIONS}

The earliest geologic reports on the Eureka Creek grea deal mainly with the geveral geology and its bearing on the early economic development of Alaska resources. The earliest account seems to be hinat of Mendenhall (1900) who, with a military expedition in 1898, followed a route to Tangle Lakes (pl. 1) and along the east side of the Delta River. Four years later, Mendenhall and Schrader (1903) returned to make a reconnaissance lopographic and geologic map of a large area that includes a portion of the area around the Delta River. The discovery ol placer gold on Valdez Creek in 1903 generated furtlicr interest in the surrounding bedrock geology. The first definitive geologic map, still accurate in many respects, is that of Moflit (1912). He described that part of the Alaska Range in the vicinity of the Delta River and Eureka Creek as consisting of a bell of Carboniferous and posl-Carboniferous sedimentary and igneous rocks lying between older schists to both the north (north of the McKinley strand of the Denali fault) and the south (south of the present Denali Highway). He considered the structure as a simple synclinorium, but recognized the possible complexily due to faulling.

A compilation by Moflit (1954) of his own work in the Alaska Range from 1912 and of others since then contains only minor changes in his 1912 version of the Eureka Creek area. Geologic mapping programs since then have been undertaken by the Alaska Division of Geological and Geophysical Surveys and the Universily of Alaska. Reconnaissance studies by Rose $(1965,1966)$ and Stout (1965) provide the basis on which additional mapping was completed as parl of this sludy north of Eureka Creek. Additional mapping efforts by Rose (1966b) and Rose all Saunders (1965) in the Amphitheater Mountains, and Moffir (1912) provided the only existing geologic maps for the area south of Eureka Creek prior to this study.

\section{ACKNOWLEDGMENSS}

I acknowledge with pleasure the Tinancial and logistic 
support of the Alaska Division of Geological and Geophysical Surveys during the course of this study. In particular, Dr. T.E. Smith afforded fixed-wing and helicopter support for access to the more remote areas. Drs. Jonathon Callender, University of New Mexico, and J.B. Brady, Harvard University, provided me with able assistance in 1971, when a portion of the map area north ol Rainy Creek was investigated. Mssrs. R.J. Beltrame, Gary Gaynor and J.E. Quick, all of the University of Minnesota, provided assistance during the 1973 field season. To them I express my gratitude.

\section{GEOLOGIC SETTING}

The oldest known rocks in the Eureka Creek area consist of fossiliferous bedded sandstomes, siltstones, and silty limestones of Early Pennsylvanian age (Rowett, 1969) exposed north of Rainy Creek and along the Delta River and Phelan Creek in the northeast corner of the map area (fig. 2 and pl', 1). The section is underlain by unfossillferous dacite crystal tuff and volcanic breccias believed also to be of Pennsylvanian age (Stout, 1965). These rocks are faulted against younger metamorphic rocks of the Maclaren Belt (Smith, 1971: Smith and Lanphere, 1971) to the north. The only evidence for an older basement is south of the Denali Highway near 'Tangle Lakes, where well-foliated greenschist and amphibolite of possible pre-Carboniferous age (Rose and Saunders, 1965) are found. The precise age of these racks is not known.

The predominantly subaerial pyroclastics and flows of Pennsylvanian age grade into fossiliferous Permian limestones and volcanics (Petocz, 1970). The rocks are predominantly marine, and represent the youngest known Upper Paleozoic sediments in the Alaska Range. The entire Upper Paleozoic sequence is apparently correlative with similar rocks in the Chulitna district (Claxk, Clark and Hawley, 1972) south of Mt. McKinley. They are also reported east of the present area near Gulkana Giacier and in the Nabesna area (Richter and Jones, 1970). These authors interpret the stratigraphic relationships as a record of an island arc developed direclly on oceanic crust followed by subsidence to a shallow.water platform.

Overlying these rocks south of Eureka Creek (pl, 1) is a thick section of mafic volcanics and pyroclastics believed to be Triassic. Mofitt (1912) first correlated these rocks with the Nikolai Greenstone of the Chitina Valley now considered to be late Middle to early Late Triassic in age (MacKevett, 1969). Most of the Amphitheater Mountains are underlain by these mafic volcanics now referred to as part of the Amphitheater Group (Smith, 1974a, b). The central axis of the Amphitheater Mountains is the axial trace of a broad syncline (hereafter referred to as the Amphitheater syncllne) that repeats the volcanic section to the south. Hence that portion of the stratigraphic section younger than Middle or Late Triassic is not exposed.

Younger Mesozoic sedimentary and volcanic rocks in the Eureka Creek area are lectonically separated from older rocks by the Broxson Gulch Turust fault (Rose, 1965). The argillites, sillstones, and silty limestones

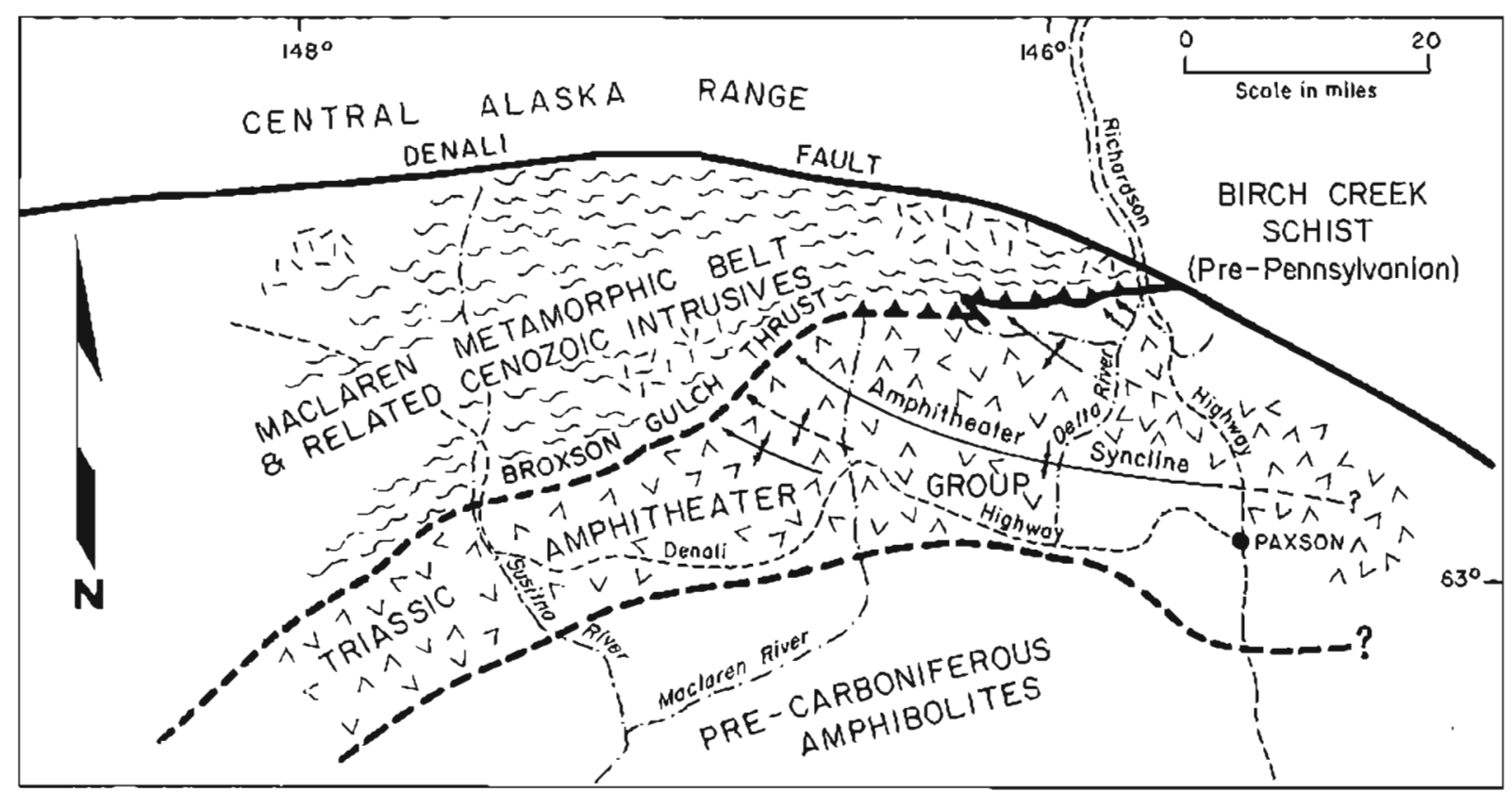

Figure 2. Generalized geologic map of the central and east-central Alaska Range. Sources of data are referenced in text. 
north of Eureka Creek are part of the Maclaren metamorphic belt (Smith, 1970b; Smith and others, 1972; Smith and Turner, 1973). The crystalline schists of this belt were first recognized in the Eureka Creek area by Rose $(1965,1966)$ and subsequently studied by Stout (1972). The low-grade parts of the beit in the Clearwater Mountains are apparently post-Upper Triassic, but not younger than Late Jurassic (Smith and Lanphere, 1971). Fossils recently dlscovered by Smith (1974a) from conglomerate exposures in the Maclaren Belt are Upper Jurassic. The widespread argillites and their meta. morphosed equivadents in the Maclaren metamorphic belt are lithologically equivalent to rocks in the GravinaNutzotin belt near Mientasta Pass (Rlchter, 1967) and therefore may be as young as late Early Crelaceous (Berg and others, 1972). The marine flyschilke argillites, graywackes, and interbedded volcanics of the Gravina. Nutzotin bell depositionally overlie Upper Paleozoic and Triassic rocks elsewhere in Alaska and are interpreted by Berg, Jones, and Richter (1972) as part of a deformed upper Mesozoic magmatic arc.

Radiometric dating of metamorphic biolite and hornblende from schists of the Maciaren belt yield regtonal metamorphic ages from 66 to $67 \mathrm{m.y}$. (Smith and Turner, 1973) and confirms its Late Cretaceous development.

Supracrustal rocks of the Maclaren belt have been intruded by numerous stocks and stills ranging in age from 143 m.y. for alkall gabbro (Smith and Lanphere, 1971) to approximately $30 \mathrm{~m} . \mathrm{y}$. for granodiorite and quartz monzonite (Smith and Turner, 1973). None of these intrusive rocks can be directly correlated with rocks intruded into the tectonically separated Mesozoic and Paleozoic sections to the south. The felsic intrusives do seem to correlate, however, with two of the three main intrusive epochs of the Alaska-Aleutian Range batholith (Reed and Lanpbere, 1970, 1973). The latter are Late Cretaceous-Early Tertiary and Middle Tertiary.

South of the Broxson Gulch Thrust, granodiorite intrusive into basalts of the Amphitheater Group is dated at $125 \mathrm{~m} . \mathrm{y}$. (Smith and Turner, 1973). Numerous ultramafic rocks, including dunite and peridotite, are younger than the granodiorite but have not as yet been dated by direct means.

The intrusive utramafic rocks are apparently of different ages. A layered sequence of perfdotite and dunite south of Eureka Creek (fig. 2) may be preJurassic, whereas the massive dunites along the base of the Broxson Gulch Thrust appear to be Tertlary (Stout, 1965). The latter rocks define a northeast-striking belt that extends to the Denali Fault, and then east-southeast along that great lineament (Stout, 1972).

Tertiary conglomerate, coal-bearing sandstone, and a lew volcanic gows (all probably post-Oligocene) un. conformably overlie all older rocks. They are broadly folded in most areas, but are strongly deformed and faulted near the Broxson Gulch Thrust. This suggests that motion on the thrust fault-and perhaps on the Denali Fault as well-is as young as Middle to Late Tertiary.

\section{STRATIGRAPHY}

The pre-Tertiary stratifled sedimentary and volcanic rocks of the Eureka Creek area are divided into two suites: 1) Pre-Jurassic sedimentary and volcanic rocks south of the Broxson Gulch Thrust, and 2) JuraCretaceous metamorphic rocks north of the Broxson Gulch Thrust.

This division facilitates comparison of the lithology and geologic history of rocks separated by the Broxson Gulch Thrust. ' It also serves to jllustrate the fundamental tectonic and stratigraphic differences between these two suites. Both are unconformably overlain by Tertiary sediments and deposits of glacial origin. A summary of the stratigraphic succession is given in table 1.

\section{PRE-PENNSYLVANIAN(?) GREENSCHISTS AND AMPHIBOLITES}

Well-foliated greenschists ard amphibolites are exposed in the low-lying hills south of the Denali High way near Tangle Lakes (pl. 1). These rocks are part of the 'Carboniferous(?) greenstone, schisi, and limestone' unit recognized by Mofít (1912, 1954) and Chapin (1918) north of the west fork of the Gulkana River. The west-lirending belt extends from the Richardson Highway to at least the Susitna River, a distance of over 100 miles. Rose and Saunders (1965) later examined these rocks south of Paxson Mountain and, based on their higher rank metamorphlsm relative to the Triassic Amphitheater Group, concluded that they are probably pre-Triassic. They are grobably the oldest rocks exposed in the Eureka Creek area.

At the most northerly outcrops near Tangle Lakes (pl. 1), interlayered rusty schists and greenschists dip steeply to the north. These are fine-grained rocks with a well-developed metamorphic fabric. Some deeply weathered diorite or granodiorite sills penetrate the schists at this locality. They appear to be unmetamorphosed.

Further south, amphibolites become common and the rusty-weathering units are absent. Thin-section examination of representative amphibolite samples (table 2) reveals a pale blue-green hormblende with apparently unreacted cores of colorless clinopyroxene (fig. 3). Biotite is common in the finer-grained varietses. Epidote and actinolite or very pale hormblende occurs in a few calcmagnesian layers.

Most of the thin sections of amphibolites have approximately 5 volume-percent magnetite. This prob-

\footnotetext{
Usage of thrust will apply loosely to all low-angle faults in the zone of roovement (pL 1 ).
} 
Table 1. Straligraphes aummary af layered rocks in the Eureka Creck area.

$\begin{array}{ll}\text { Quatemary: } & \begin{array}{l}\text { Cilacial lill: Largely unconsolidated } \\ \text { Ground mornin? }\end{array}\end{array}$

\section{UNCONFORMITYY}

Oligocene:

Jurassic:

(Crelaceous?):

'Triassic

Perminı

Pennsylvaniun:

Pre-Pennsylvanian ably accounts for the high aecomagnetic inlensily obsterved by Alldreason and alhers (1964) over lhis poorly exposed lerrane.

Careful examination of the foliation and allitudes of primary composilional layering shows that the rocks

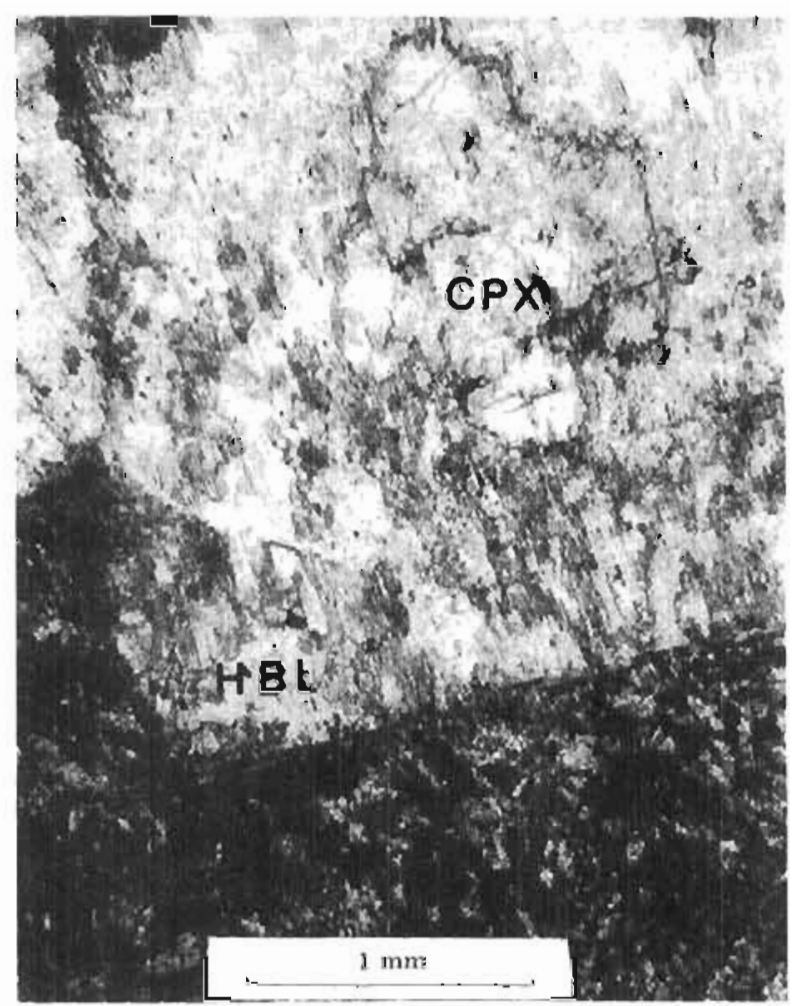

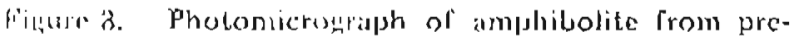
Pesusylvaman(?) toralle near 'Tangle Lakes. Hornblende porphyrolstasts (IIBL) havr relict clinopyroxene $(C P X)$ cores. Suecimen $A A-\{\}-1$.

'Table 2, Modes of represenlative specimens from Pre-Pennsyluanimu(!) preenschisls and amphiboliles from near Tangle Lakes.

I Andus are from thin section 1,5 visual estimute. I

\begin{tabular}{|c|c|c|c|c|c|}
\hline \multirow[t]{2}{*}{ Specimen No. } & A $4-3-1$ & JS- $801 \mathrm{~A}$ & JS-801 B & JS-802 & A5-1-1 \\
\hline & \multicolumn{5}{|c|}{ Modes } \\
\hline AcLinolite & - & - & - & 10 & - \\
\hline Biotite & 5 & 20 & 20 & & 10 \\
\hline Chlorite & - & 10 & 25 & 30 & 10 \\
\hline Epidole & 2 & - & - & 10 & 10 \\
\hline Hornblende & 70 & 30 & 10 & - & . \\
\hline Hemalits & - & & & & 10 \\
\hline Makinelilc & 5 & 4 & 5 & 5 & - \\
\hline P'agioclase & - & 35 & 10 & 5 & - \\
\hline (An content) & . & 30 & 30 & 30 & - \\
\hline Pyroxene & 10 & - & - & . & - \\
\hline Quartz & & - & & 35 & 30 \\
\hline Sericile & - & - & & 5 & 30 \\
\hline
\end{tabular}


have been intensely folded on an outerop scale. This observation is noted here because it contrasts markedly with the rather uniform dips of the Triassic Amphithealer Group exposed norlts of the Denali Highway. There, the metavolcanics are only weakly recrystallized and dip at low to moderate angles to the north. Unfortunately, the contact is covered by an extensive region of glacial drift in the vicinity of Tangle Lakes. There is sufficient outcrop to conclude, however, that the thick Pennsyivanian and Permian sections discussed elsewhere in this paper are missing. A faull or an unconformity or both are possible interpretations. There is some basis for preferring an unconformity becallse of the absence of Lower and Middle(?) Triassic rocks else where in Alaska.

\section{TETELNA COMPLEX}

Outcrops of Pennsylvanian sedimentary and volcanic rocks define a wedge-shaped area (lig. 2) bouncled on the north by the Jura-Cretaceous Maclaren metamorphic belt and on the south by the Permian Mankomen Group. The best exposed regions are in the deeply dissected canyons west of the Delta River and along the east side of the Ricliardson Highway. The section extends westward beyond Broxson Gulch, where it is faulted oul between imbricate thrust faults (pl. 1).

Several attempts have been made to divide the Pennsylvanian rocks into mappable units. Stout (1965) originally defined eight informal formations on the basis of differences in lithology. These are, in order of decreasing age:

1. Andesile flow unit

2. Interbedded siliceous tuff and tutfaceous limestone unil

3. Siltstone and mudstone unit

4. Crystalline limestone unil

5. Gray wacke and dark tuffaceous sandstone unit.

6. Dacite quartz porphyry

7. Calcareous shale and siltslone unit

8. Volcanic breccia and dacitic turf.

Collectively, the exposed section is between 9,000 and 10,000 feet thick. These are the oldest rocks exposed in the Eureka Creek area and are a part of an extensive volcanic-rich sequence east of the Delta River near Rainbow Mountain (Hanson, 1963). There, nearly 1,000 leet of dacitic tuffs and volcanic breccias intercolated with grey-green siltstone and mudstone of probably volcanlc origin are overlain by approximately 3,300 feet of bedded sandstone, siltstone, and silty limestone. Rowett (1969) estimates an aggregate thick. ness of approximately 8,000 feet.

A detailed stratigraphic sludy of the Pennsylvanian section east of the Delta River by Bond (1970, and personal communication, 1974) indicates that units 1 through 5 described by Stout (1965) and listed above are probably correlative with the lower Tetelna Complex of Atokan or Desmoinesian age, or both. The nomenclature is based on Mendentall's (1905) original usage and that adopted by Richler (1966) for several thousand feet of subgerial volcanics in the Slana district, 100 niles to the east. Units 6 through 8 listed above lithologically correlate with Bond's Richardson Highway pyroclastics; consequently, that usage will be adopted here. This formation contains cossils of Missourian(?) and Virgilian(?) age (Rowett, 1969, 1971) and its top is taken as the boundary between Pennsylvanian and Permian strata. A recetic study by Rowett and Timmer (1973) of a varied fauna of rugose corals collected near milepost 212 on the Richardson Highway establishes a lower Middle Pennsvivanian (Alokan or Desmoinesian) age for these rocks.

Rose $(1965,1966)$ further attempted to subdivide the Paleozoic strata. He distinguished the following sequence of six mappable units in order ol decreasing age:

1. Andesite, dacite, and gray wacke

2. Limestone

3. Intrusive andesite and dacite

4. Rainy Creek basalt

5. Limestone associated with Rainy Creek basalt

6. Tuff and sedlments associated with Rainy Creek basalt.

Fie)d mapping as part of the present study (pl. 1) indicales that Rose's sequence and Stout's (1965) sequence are broadly correlative. Comparison of Rose's stratigraphy with that of Stout (above) reveals that Rose's units 1 and 2 correlate with Stout's units 1 through 5. Both sets of units appear to correlate with Bond's lower Tetelna Complex. For future usage and formal nomenclature, il seems appropriate at this time to adopl the formation name Tetelna Complex in place of the incormal unils of Rose $(1965,1966)$ and Stout (1965).

The dacite quartz, porphyry of Stout (1965) and the intrusive andesile and dacite of Rose (1966) are taken in this study as the contact between Bond's lower Tetelna Complex and his Thichardson Highway pyroclastics. Extrapolation of Bond's contact (personal commun., 1974) across the Delta River to Ann Creek (pl. 1) indicates that Stoul's units 7 and 8 correlale with the Richardson High way pyruclastics.

The contact between the Pennsylvanian and Permian sections in the Eureka Creek area is not well defined because of an absence of diagnostic fossils. Rowetl (1971) has found lower Wolfcampian Cossils in thin, bioclastic limestones that are interbedded in a predominantly volcanic sequence that stratigraphyically overlies the Richardson Highway pyroclastics. These rocks correspond to the sparsely exposed volcaniclastics and nows between Ann Creek and Rainy Creek. They are also apparent stratigraphic equivalents to Rose's (1965, 1966) units 4.6, listed earlier. Rose's Rainy Creek basalt and associated limestone and cuffaceous sedi. 
ments appenr from their structural position (pl. 1) to stratigraphically overlie the uppermost units mapped by Stout (1965). They also underlie the fosstiferous limestones and sliales of the Mankomen Grorl]. Hence they are likely to be of lower Permian age.

Bond (personal commun., 1971) has mapped the equivalent succession of rocks east of Phelan Creek as the upper Telelno complex. This nomenclature is adopted here because the formation includes a wide range of lithologic lypes that are conveniently mapped (pl. 1) as a single unit. None of the thin limestones or individual volcaniclastic beds observed as part of this study could be traced laterally for more than a lew hundred feet.

Adoption of Bond's romenclature is further justified because of the difficulty in recognizing discrete lith. ologies near the west lork of Rainy Creek and Broxson Gulch. There, the presumed lower Permian rocks are strongly altered by hypabyssal intrusives. Dacite poy. phyry, gabbro, and dunice have locally rerystallized the host rocks so that even their primary bedding is obscured. Thín-section and hand-specimen examination of representalive rocks reveal pyrite, calcile, sericite, chlorite, and epidote as the most common alteration products.

Recognition of distincl lithologies is further com. plicaled by intense deformation due to raulting. At the base of the Broxson Gulch Thrust (fig. 2 and pl. 1), thrust tectonites (Stoul, 1965) are locally developed. They are generally fine grained and possess a distinctive 'metamorphic' fabric that is absent a few hundred yards from the thrust zone. A photomicrograph of a deformed andesite from the lower l'etelna Complex is shown in figure 4 . Both the formal nomenclature of the Tetelna Complex as applied to the Eureka Creek area and its approximate stratigraphic lhicknesses are summarized in ligure 5.

Petrographic observations of several representative thin sections (table 3) as well as hand specimen ob- servations indicate that nearly the entire Tetelna Complex is volcanic or volcaniclastic in origill. Approximately 75 percent of the section, or 7,000 feet, consists of pyroclastic rocks of predominantly dacitic composi. tion. Approximately 20 percent of the section consists

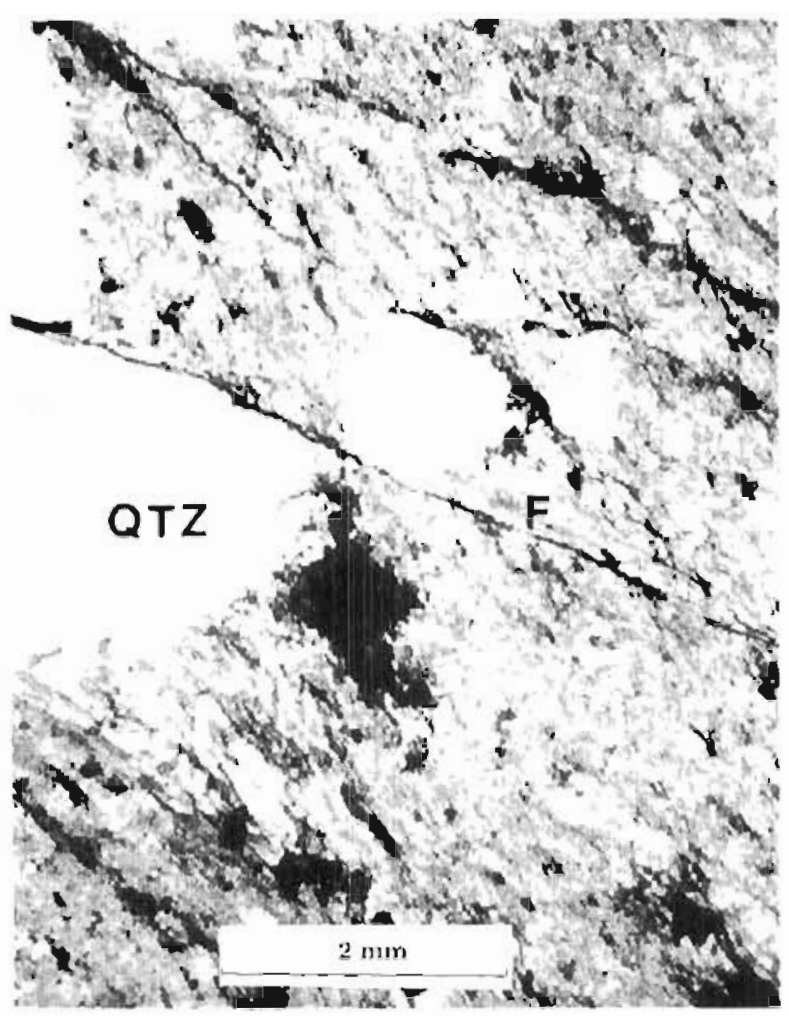

Figure 4. Photomicrograph of highly deformed andesite at the base of the Broxson Gulch Thrust. Quartz phenocrysts (QTZ) are broken by microlaults (F). and a pervasive metamorphic labric is developed. Specimen JS-193.

Table 3. Modes of represenlative specimens from the Pennsyluanian and Permian Telelia Complex. ISpecimens IS-190, 193,210,327, and 377 from he lower Tetelni Complex; remaloing: specimens from the upper Tetelna Corplex-I

\begin{tabular}{|c|c|c|c|c|c|c|c|c|c|}
\hline \multirow[t]{2}{*}{ Specimen No. } & JS-336 & JS-377 & JS- 280 & JS. 327 & JS-210 & JS-382 & JS-190 & JS-381 & JS-193 \\
\hline & \multicolumn{9}{|c|}{ Modes } \\
\hline Actinolite & . & 40 & - & - & . & - & - & 30 & - \\
\hline Chlorice & - & 5 & - & 2 & 5 & 10 & 20 & - & - \\
\hline Epidote & 5 & 3 & - & 1 & - & - & - & - & 10 \\
\hline Magnetite & 5 & $\cdot$ & 10 & - & - & 2 & - & - & - \\
\hline Opaque malerial & 40 & 10 & 10 & 1 & - & 16 & . & 20 & 10 \\
\hline Plagioclase & 20 & 15 & 10 & 55 & 7 & 13 & 10 & 30 & - \\
\hline Quart: & 30 & 5 & 20 & 25 & 20 & 40 & 30 & $\cdot$ & 40 \\
\hline Sericite & - & 22 & 10 & 12 & 40 & 20 & 40 & - & 40 \\
\hline $\begin{array}{l}\text { Volcanic rock } \\
\text { iragments }\end{array}$ & - & - & 10 & 6 & 28 & - & - & 20 & . \\
\hline
\end{tabular}




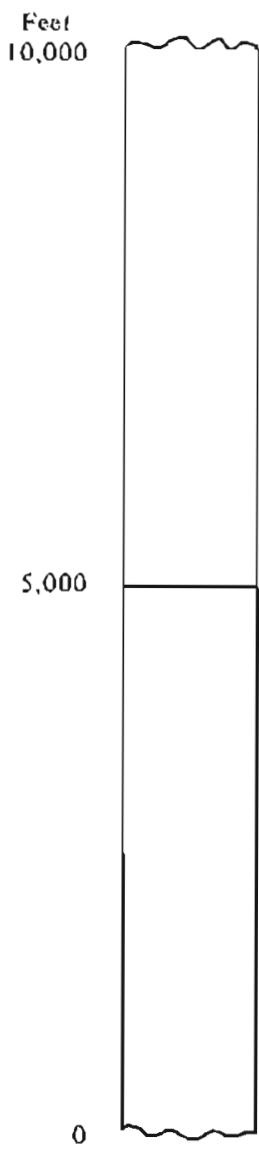

\section{RICHARDSON HIGHWAY PYROCLASTICS \\ (Pennsylvanian)}

Dacitic to andesilic pyrociastics. Dacle porohyry inlerbedded with siliceuns curli, shalc, and aggiomerate.

\section{LOWER TETELNA COMPLEX (Pennsylvanian)}

Interbedded lufiaceous sandstone. graywacke, uffaceuns limeslone. and andesitic to dacilte volcanics.

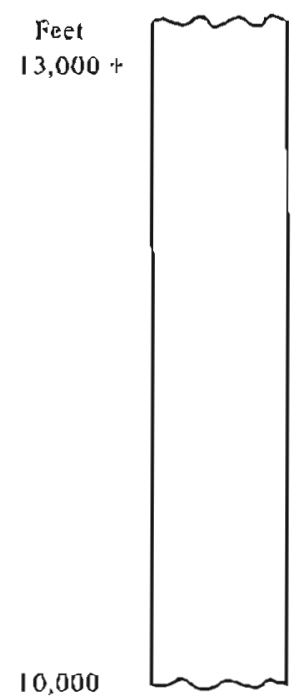

\section{UPPER TETELNA COMPLEX} (Permian)

Dacilic 10 basaltic voleanics and pyroclastics interbedded with unpure bioclastic limeslone, sillccous func-grained lull. Iulaic vol. connc sandsionc, ind agghtomerite.

Figure 5. Summary of stratigraphy within the Pennsylvanian and Permian Telelna Complex.

of volcanic fows whose compositions appear in liand specimen to range from dacite lo basalt. The rest of the section consists of limestone, tuffaceous limestone and sediments, and feldspathic sandstone (gray wacke). These results support Bond's (1970) interprelation that the upper Paleozoic stratigraphic succession records an ancient island-arc environment.

\section{MANKOMEN GROUP}

Marine strata of lower Permian age are well exposed in Eureka Creek and in Rainy Creck near the northeast corner of the study area. There appears to be a gradabional contact between subaerial lavas and pyroclastics of the Tetelna Complex to the north and marine shales or argillites and limestones that constitute the basal part of the Mankomen Group to the south. The south. dipping section is approximately 2,000 feel lhick on Rainy Mountain (pl. 1) and is cut by numerous daults of unknown displacement. The contact belween the Mankomen Group and the presumed base of the Triassic Anphitheater Group is exposed 3 miles northwest of Raıny Mountain.

The lithology and biostraligraphy of the Mankomen Group on Rainy Mountain and along the Delta River has been studied extensively by Petocz (1970) and will only be summarized here. The most distinctive rocks are thick, fossiliferous limeslones, which constitute approxi. mately 80 percent of the strata. Brachiopods, bry. ozoans, crinoids, and both solitary and colonial rugose corals ore common. Interbedded black shales and thin, bioclastic limestones are prominently exposed along the north-facing bluft's on Rainy Creck. Eiglileen species of fusulinids studied by Petocz (1970) from these rocks indicale a lower Permian age.

Coral zonation (Rowett, 1970) indicates that the massive bioclastic limestones at the top of the section on Rainy Mountain may have been deposited in Leonardian time. According to Rowett, an eastward marine transgression commenced at this time and ultimately inundated the Tetelua volcanic pile that was simul. taneously accumulating in the Slana district.

The stratigraphy of the Mankomen Group south of Rainy Mounlain is less well understood. A thick section of fossiliferous limestone and interbedded shale in the lower gorge of Eureka Creak south of Rainy Mountain (pl. 1) was noted by Moffit (1954) and Rose (1965). but was nol studied in detail. Examination of fossils collected from the limeslone between Eureka and Rainy Creek as reported by Rose $(1965$, p. 10) indicates a 
probable post-Wolfcampian age. Field mapping as patt of this study (pl. 1) in the gorge of Eureka Creek indicates that this is the same limestone-shale sequence as exposed on Rainy Mountain. The limestone is lypically coarsely bedded and displays dark-blue, gray, or buff weathered surfaces. Crinoid parts, brachlopods, and corals are abundant-just as they are on Rainy Mountain. Interbedded black to gray shales range from 2 to 40 feet thick. Locally they contain abundant bryozoans.

\section{Feet}

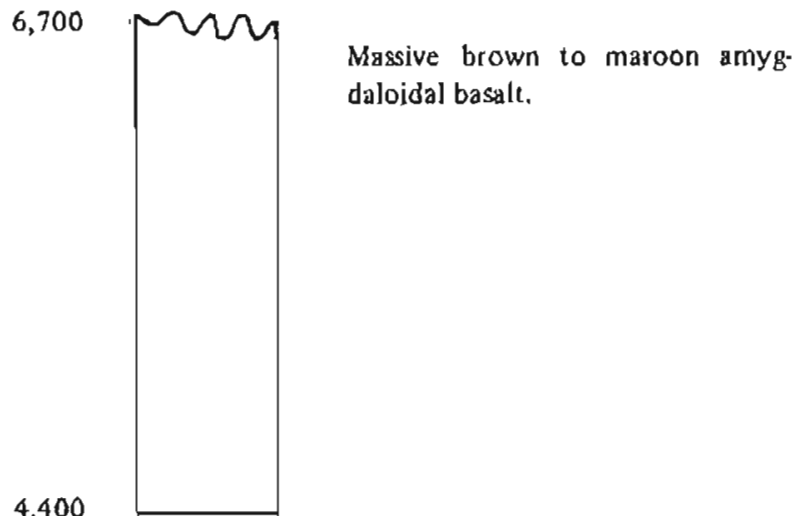

Massive, thick-bedded light-gray to buff limestone.

Shale and limestonc.

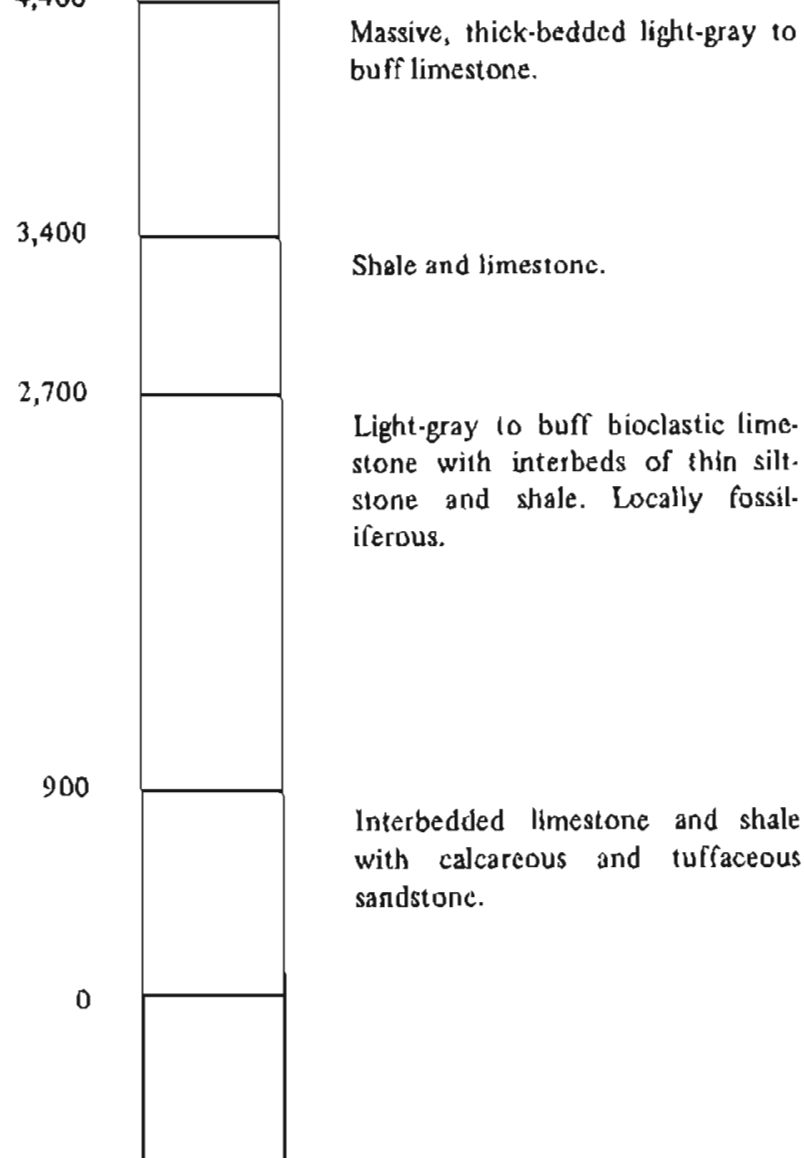

Interbedded limestone and shale with calcarcous and tuffaceous sandstonc.
The apparent stratigraphic sequence as observed between Rainy Mountain and Eureka Creek is shown in figure 6 . In addition to the interbedded limestone and black shale, two cormations of brown to maroon amygdaloidal basall occur within the sequence north of Eureka Creek. The basalts are lithologically identical, but they differ in thickness. The basalt nearest Eureks Creek is approximately 1,000 feet thick, whereas the basalt nearest Rainy Creek is approximately 3,400 feet

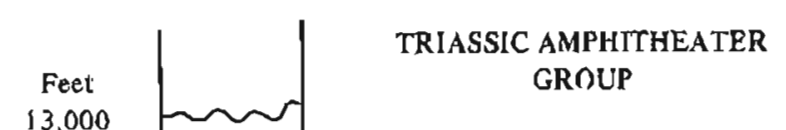

Interbedded black shale and limestone.

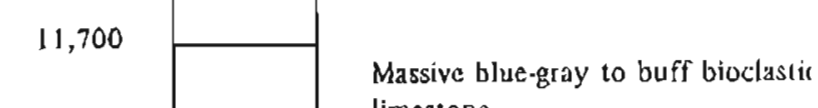
limestone.

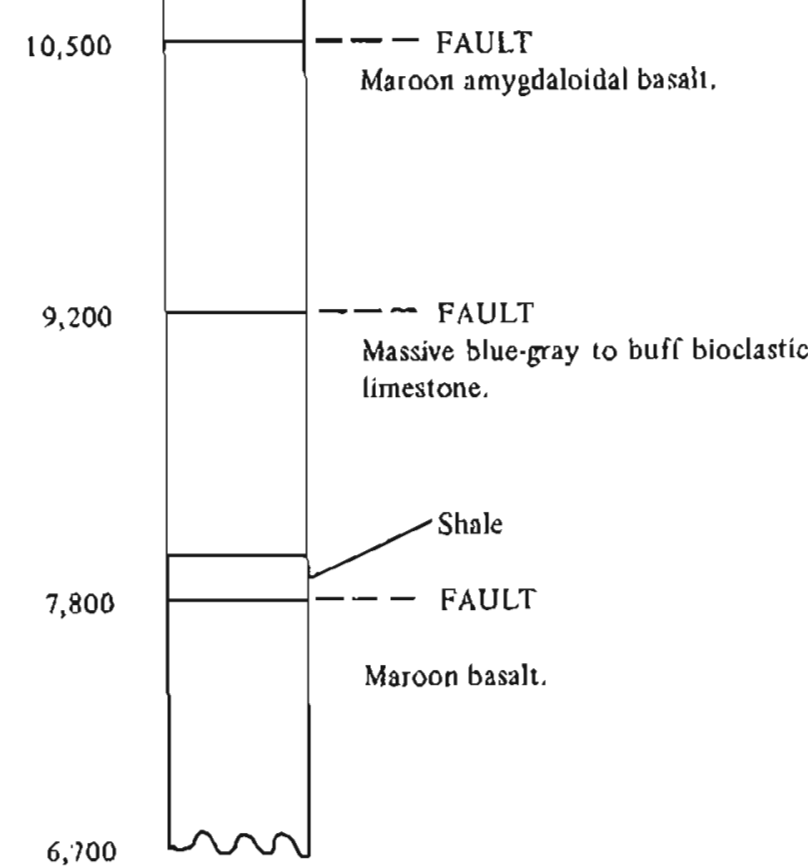

Figure 6. Summary of stratigraphy within the Permian Mankomen Group. 
thick. The base of the latter is exposed within 1 meter of interbedded limestone and shale on the north-lacing slope 3 miles northwest along strike from Rainy Mountain. As there is no evidence for faulting, it is interpreted as a primary depositional contact.

The similarities of the shale-limestone-basalt sequences shown in figure 6 suggest that faulting may be responsible for the repetition. The aggxegate stratigraphic thickness from the base of the Mankomen Group north of Rainy Mountain to the base of the extensive basalt terrane (Triassic Amphitheater Group) south of Eureka Creek is approximately 13,000 (eet. The massive fossitiferous limestones are near the base of the apparent section, whereas they are near the top of Permian sections elsewhere in Alaska (Mendenhall, 1905; Mofflit, 1954). This further suggests that the Mankomen Group as exposed on Rainy Mountain is repeated in Eureka Creek because of faulting.

In view of this interpretation, the 3,000-foot section of brown to maroon amygdaloidal basalt exposed between Rainy Creek and Eureka Creek is considered here as the base of the Triassic Amphitheater Group. This interpretation must be considered tentative inasmuch as amygdatoidal basalts have been described elsewhere within Permian rocks (Capps, 1916; Moffit, 1943, 1954; Richter and Matson, 1969). The basalts recognized by Richter (1966) and Rowett (1971) within the Permian section near Slana are als included within the Tetelna Complex, however.

In the absence of diagnostic fossils at the presumed base of the Amphitheater Group, there is little evidence that exists within the Eureka Creek area to document the Pernian-Triessic unconformity recognized elsewhere (Force, 1973). The oldest Triassic fossils in the overlying Amphitheater Group are Middle-Late Triassic (Moffit, 1912; Smith and Lanphere, 1971), but there are several thousand feet of lavas stratigraphically below the fossiliferous horizons.

\section{AMPHITHEATER GROUP}

Weakiy metamorphosed basalt, andesite, and tuflaceous rocks of the Amphitheater Group are well exposed in the Amphitheater Mountains north of the Denall Highway (pl. 1). The rocks were first mapped on a reconnaissance basis by Moffit (1915), who recoginized their distribution as a band, 15 to 20 miles wide, extending from the Susitna river east to the Richardson Highway. The rocks were also described by Chapin (1918) and Ross (1933) as consisting of metamorphosed basalt and andesite flows, breccias, and tuffs referred to collectively as greenstone. Both Molfit (1915) and Martin (1926) recognized the similarities with the Nikolai Greenstone (MacKevett, 1969) in the Chitina Valley and suggested their correlation. The Nikolai Greenstone is Middle to Late Triassic and is probably correlative with extensive basalt sequences of the same age elsewheve; these include presumed Amphitheater Group equivalents east of Slana and along the international border (Richter, 1967), the Mush Lake Group near Kluane Lake (Muller, 1967) and the Karmutzen Group on Vancouver Island (Surdam, 1968). Hence the section exposed in the Amphitheater Mountains and elsewhere along the soutb side of the central Alaska Range may represent a portion of a belt that extends for more than 1500 miles.

Specific studies in the Anphithealer Mountains did not commence until the reconnaissance mapping effort by Rose (1966b). Rose and Saunders (1965) applied the name 'Amphitheater basalt' to the metabasalts exposed to Paxson Mountain south of the Denali Highway ( $\mathrm{pl}$. 1). These rocks dip to the north and are overlain by andesitjc tuffs and agglomerates that Rose (1966b) includes as part of the 'Amplitheater formation'. Smith (1974) subsequently elevated the entire unit to group status because of its varted lithology and complexily.

Geologic mapping as part of this study reveals that the Amphitheater Group in the Amphitheater Mountains and vicinity consists of three distinctive lithologic sequences (fig. 7). They are given formational status because of their lateral continuity and intportance in understanding the regional stratigraphy. Collectively, the three formations are approximately 40,000 feet thick.

\section{PAXSON MOUNTAIN BASALT}

This formation is named after Paxson Mountaln in the southeast corner of the map area (pl. 1), where the characteristic olive-gray lo dark-green matabasalts are well exposed and readily accessible. It is the oldest formation in the Amphitheatcr Group, and on Paxson Mountain and nearby hills it dips at moderate angles to the north. Near Rainy Creek, 20 miles to the north, the Paxson Mountain basalt directly overlies the Permian Mankomen Group and dips at moderate to steep angles to the south. The intervening structure, the Amphitheater syncline, is responsible for the present distribution of the formation. It is discussed on pages 2627.

South of Paxson Mountain, the Permian section is apparently missing. Instead, the Paxson Mountain Basalt overlies, perhaps unconformably, the well-crystallized greenschists and amphibolites considered by Moffic (1954) as among the oldest rocks of the Copper River Basin. In the map area of plate 1 , these presumed preCarboniferous metamorphic rocks are exposed only in the low-lying hills south of the Denali Highway near Tangle Lakes.

The oldest rocks recognized in the Paxson Mountain Basalt are brown to maroon amygdaloidal basalts exposed between Rainy Creek and Eureka Creek (pi. 1). They appear more strongly altered than similar rocks 


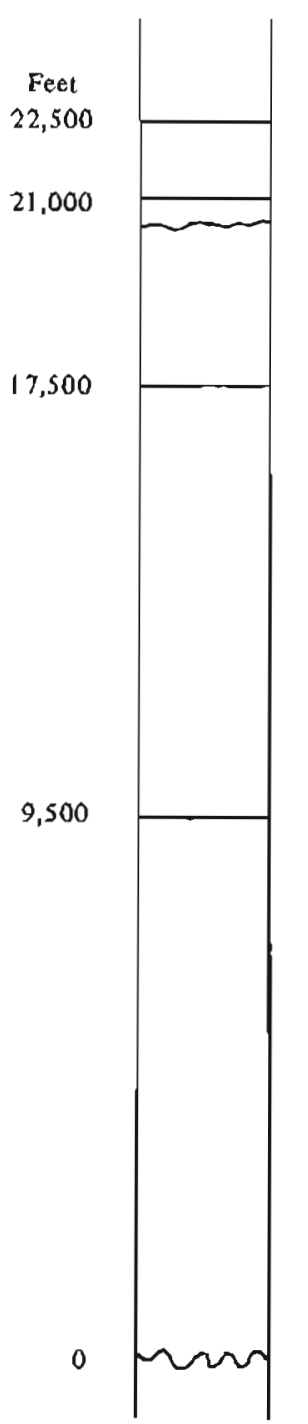

\section{PAXSON MOUNTAIN BASALT}

Green 10 olive basalt with minor maroon amygdaloidal basalt near base.
Pillowed andesite flows at top of section. Local pillow basali (TRtlb).

Voleanic tuffs and agglomerate interbedded with thin flows. Some pillowed.

Siliceous, finely stratified water-laid tuffs. Local impure limestone.

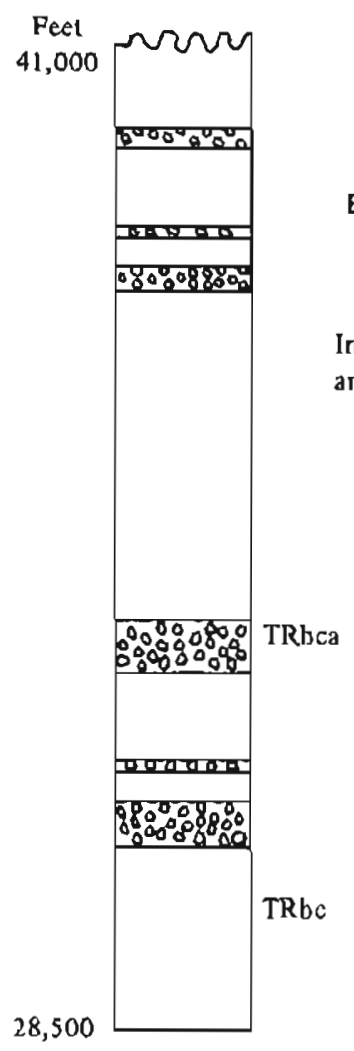

Interlayered gray to green basalts and amygdaloidal basalc (TRbca).

\section{MANKOMEN GROUP}

Figure 7. Summary of the nomenclature and stratigraphy of the Triassic Amphitheater Group.

higher in the section as evidenced by their relative softness and secondary mineralogy. The maroon colot in many outcrops is due to fine-grained hematite or limonite contained in the aphanitic groundmass. Porphyritic varieties are present, but the plagioclase is invariabiy albite and has a distinctive pale-green color owing to fine-grained secondary epidote and chlorite. These alterations commonly impart a splotchy red-andgreen aspect to the rock on fresh surfaces that is rather distinctive.

South of Eureka Creek and on Paxson Mountain, the more abundant dark-green to olive-gray basalts that occur higher in the formation form massive, resistant outcrops. These rocks are finer-grained and harder than those lower in the section. This is perhaps due to the sparse occurrence of amygdular zones in contrast to the older basalts. The amygdular zones are the only reliable indicators of primary layering, and when they are absent (such as on Paxson Mountain), structural relationships are dieflcult to determine.

Many of the outcrops on Paxson Mountain and elsewhere in the formation appear quite fresh and little altered. Thin-section examination in every case, how. ever, reveals that the plagioclase feldspar is completely recrystallized to albite. Commoniy, the primary augite has reacted to form chlorite or actinolite, but in some sections it retains its original chemistry despite the plagioclase alteration. The opaque oxides, mainly ilmenite and magnetite, are usually skeletal and highly oxidized.

The secondary mineralogy of the amygdules (fig. 8) is rather distinctive. The amygdules are typically zoned 


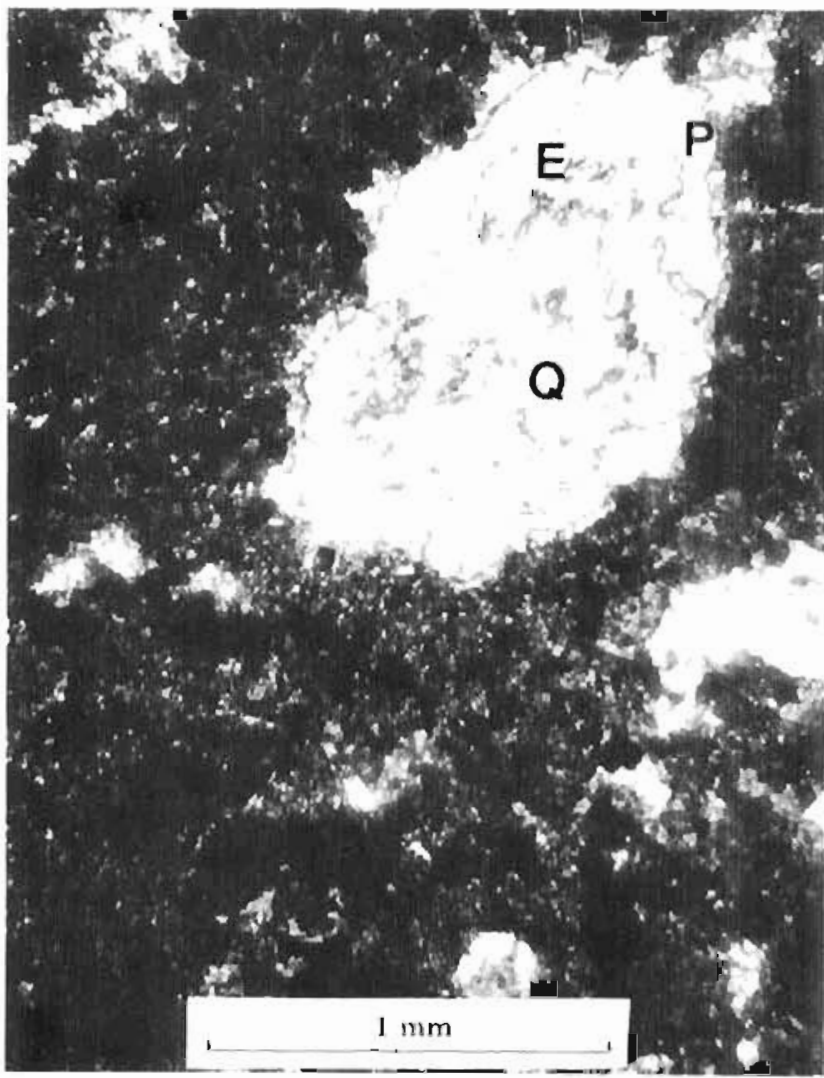

Figure 8. Pholomicrograph of amykdaloidal basalt within the Paxson Mounlain Basalt near Rainy Creek. Amyedules consist of pumpellyite (P), epidon. $(E)$, and quartz $(Q)$ set in a groundmass of magnetile. parlly recrystallized augite, and secondary mineruis. Specimen A 5-8-4B.

in a radial inanner, and the sequence of phases from rim lo core is varied. The most common sequence is chlorite. epidole-pumpellyite-prehnite-quarlz; bul calcite, laumontile, clinozoisite, and albile atso occur in some cases. Rarely, the amygdules will con lain malachite (and once, bornite). The most remarkable observation is that the mineralogy and sequence of phases is practically the same throughout the entire thickness of the Amphitheater Group where amygdules are found. Similar observalions elsewhere in the Amphithealtur Group (Smith, 1974), in the Nikolai Greenstone (Mackevett, 1965), and in the Karmutsen Group (Surdnm, 1968) on Vimcouver Island suggest that the amygchle mineralogy is imherent to the rock and not necessarily related to local thermal gradients. The latler interpretalion is invoked by Smith and Turner (1974) to account for the prelinite and pumpellyile in the Ainphitheater Group at the base of the Maclaren melumorphic belt in the Clearwater Mountains. This probjem is currently under investigation as jarl of a separate study.

The lotal thickness of the Paxson Mountain Basalt can only be bracketed owing to incomplete exposure.
Soulh of Eureka Cretk, the amygdaloidal maroon basalts apparently grade into the more typical dark-green to olive basalts over a stratigraphic distance of about 5,000 feet. Al Fish lake, the basalts are apparently in fault contacl with the Fish Lake ultramafic complex (ol. 1). On the southeast limb of the Amphitheater syncline, a maximum of 10,000 feel of basall. is exposed mainly on Paxson Mounlain and in the low hills to the norlh. Reliable atlitudes are scanty in this area, however, so the possibility ol laulling or folding cannot be ruled out. Representative modes of the Paxson Mountain Basalt are given in table 4.

\section{TANGLE LAKES FOIRMA'TION}

The type locality for the Tangle Lakes Formation is on the south limb of the Amphitheater syncline near T'angle Lakes and line upper Della River. The characteristic andesites, agslonnerales, and siliceous lurts dip at moderalc angles to the north at the type locality, but become west dipping in the hinge zone of the syncline. These well-layered and unmislakable volcanics can be traced almost continuously around to the north limb of the syncline, where the formation is apparently faulled against the fish Lake ultramatic complex to the north. At this locality, only the uppermost members of the formation are exposed.

On the south limb of the Amphitheater syncline just west of the Tangle Lakes ( $\rho l .1)$, a maximum thickness of 11,500 feel is inferred from the uniformly norlldipping attiludes. Of this, a maximum of 3,000 to 1,000 reel could be accounted for by diabase and diorite sills that penelrate the strata. These intrusives are very abundant south and east of Sugarloar Mountain (pl. 1), where they occupy up to 75 percent of the outcrop.

Rose (1966b) was the lirst to describe the andesilic volcanics exposed on Sugarloal Mounlain. He referred them to his informal Amphitheater formation but recognized that they were overlain by a thick sequence of metabasalts (Boulder Creek Volcanics of this report). Rose incorrectly inferred the presence of a fault east of Sugarloaf Mounlain, which facilitaled his tentative correlation of the overlying basalts with the lithologically similar Paxson Mountain Basalt. These two basalt sequences are now known to be diflerent.

Several distinct lithologies are represented in the Tangle Lakes Formation. The more prominenl of these are summarized in figure 7 . At the base of the formation, several thousand feet of well-bedded siliceous luffs and tuffaceous fine-grained sediments are exposed. The most continuous section of these rocks is found just north of Round Tangle Lake (pl, 1) along the west side of the upper Delta Kiver. The distinctive gray to green bands commonly observed on wealhered surfaces range from 0.5 lo $3 \mathrm{~cm}$ wide. Thin-seclion examination (table 4) reveals the banding due to alternating silicarich and plagioclase feldspar-rich layers. In both types, 


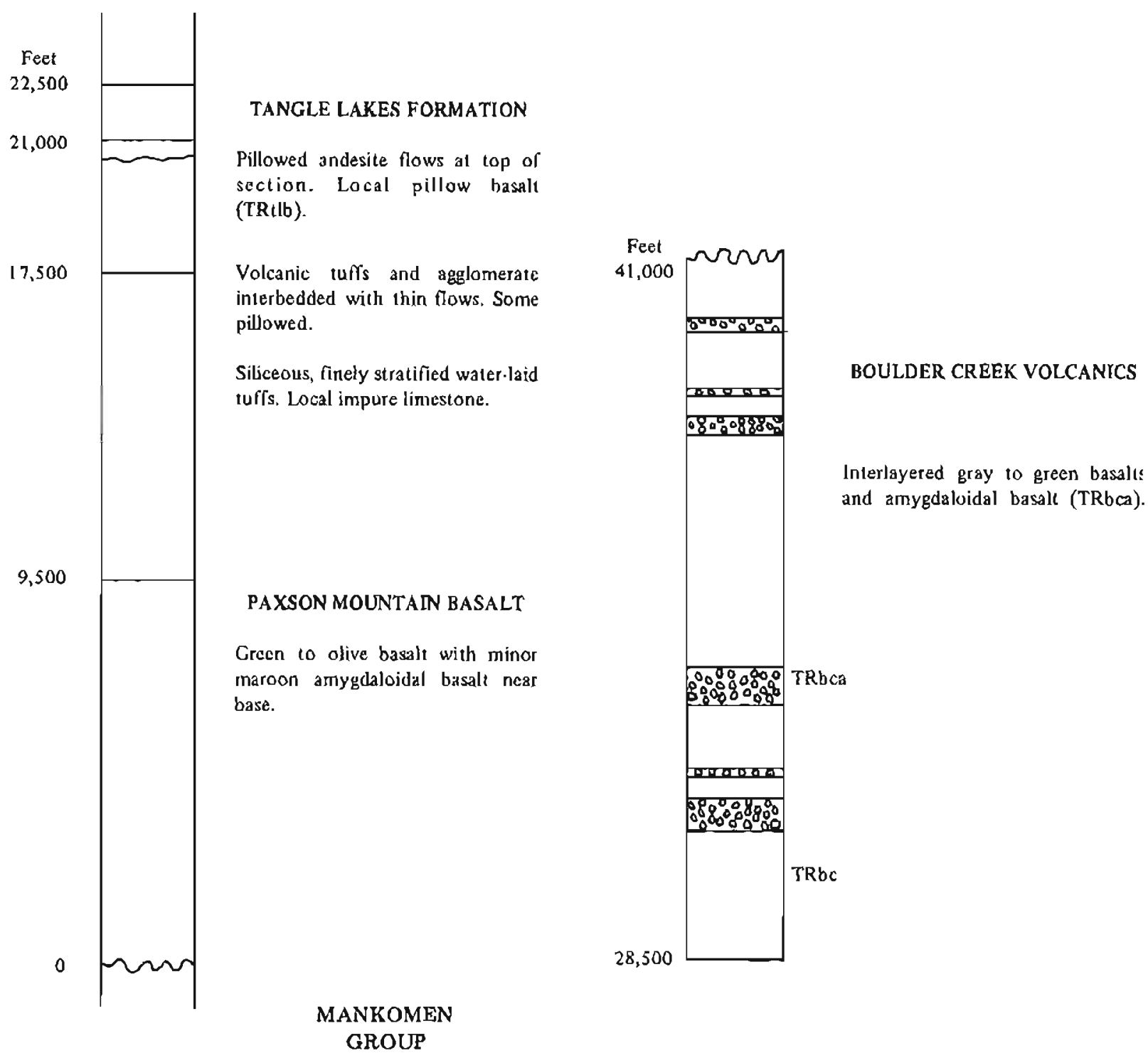

Figure 7. Summary of the nomenclature and stratigraphy of the Triassic Amphitheater Group.

higher in the section as evidenced by their relative softness and secondary mineraiogy. The maroon color in many outcrops is due to fine.grained hematite or limonite contained in the aphanitic groundmass. Porphyritic varietles are present, but the plagloclase is invariabiy alblte and has a distinctive pale-green color owing to fine-grained secondary epidote and chlorite. These alterations commonly impart a splotchy red-and. green aspect to the rock on fresh surfaces that is rather distinctive.

South of Eureka Creek and on Paxson Mountain, the more abundant dark-green to olive-gray basalts that occur higher in the formation form massive, resistant outcrops. These rocks are finey-grained and harder than those lower in the section. This is perhaps due to the sparse occurrence of amygdular zones in contrast to the older basalts. The amygdulay zones are the only reliable indicators of primary layering, and when they are absent (such as on Paxson Mountain), structural relationships are difficult to determine.

Many of the outcroys on Paxson Mountain and else. where in the formation appear quite fresh and little altered. Thin-section examination in every case, how. ever, reveals that the plagioclase feldspar is completely recrystallized to albite. Commonly, the primary augite has reacted to form chlorite or actinolite, but in some sections it retains its original chemistry despite the plagjoclase alteration. The opaque oxides, mainly ilmenite and magnetile, are usually skeletal and highly oxidized.

The secondary mineralogy of the amygdules (fig. 8) is rather distinctive. The amygdules are typically zoned 
a gray lo pale.green aphanitic matrix is common.

Several varieties of volcanic agglomerate are inter. beddeo with the liner-grained tuffs. They consist of angular volcanic clasts up to 3 feet in diameter, but dimensions in the range of a few inches are more common. The enclosed fragments all appear to be of local derivation. They include siliceous tuffs, andesite now rocks, other agglomerates, and rare tuffaceous limestone (fig. 9). Plagioclase phenocrysts can occassionally be discemed within the light. lo dark.green aphanitic groundmass. The overall bulk composition appears to be andesitic or dacitic.

Approximately 8,000 stratigraphic feel from the base of the section, andesite flows and interbedded red cherts and black, siliceous argillite or shale are predominant. Thin tuffaccous limestone and dolomitic limestone are also present. The latter rocks occur as discontinuous lenses up to 3 reet thick that can be traced no more than a few tens of feel along strike. The andesite flows are generally fine grained and distinctly lighter colored than the basalts in the overlying and underlying formalions. Thin-section examina. tion (table 1) of the light-gray' to light-green porphyritic varleties show tiny 'swallowtail' plagioclase phenocrysts (Iig. 10) embeddeos in a fine-grained to aphanitic groundmass.

The only possil evidence for the age of the Tangle Lakes Formation comes from a small hill 1 mile east of VABM TANGLE east of Tangle Lakes. There, a black calcareous argillite contains sparse fragments of a small pelecypod tentatively identified as Monotis Subcir. cularis. Pending confirmatory identification, the enclosing beds are assumed to be late Upper Triassic.

An Upper Triassic age for the Tangle Lakes formation seems reasonable in view of its lithologic similarity to fossliferous rocks of the same age else. where in the Alaskia Range. Neffit (19/2) identified Monolis Subcircularis near the presumed top of the

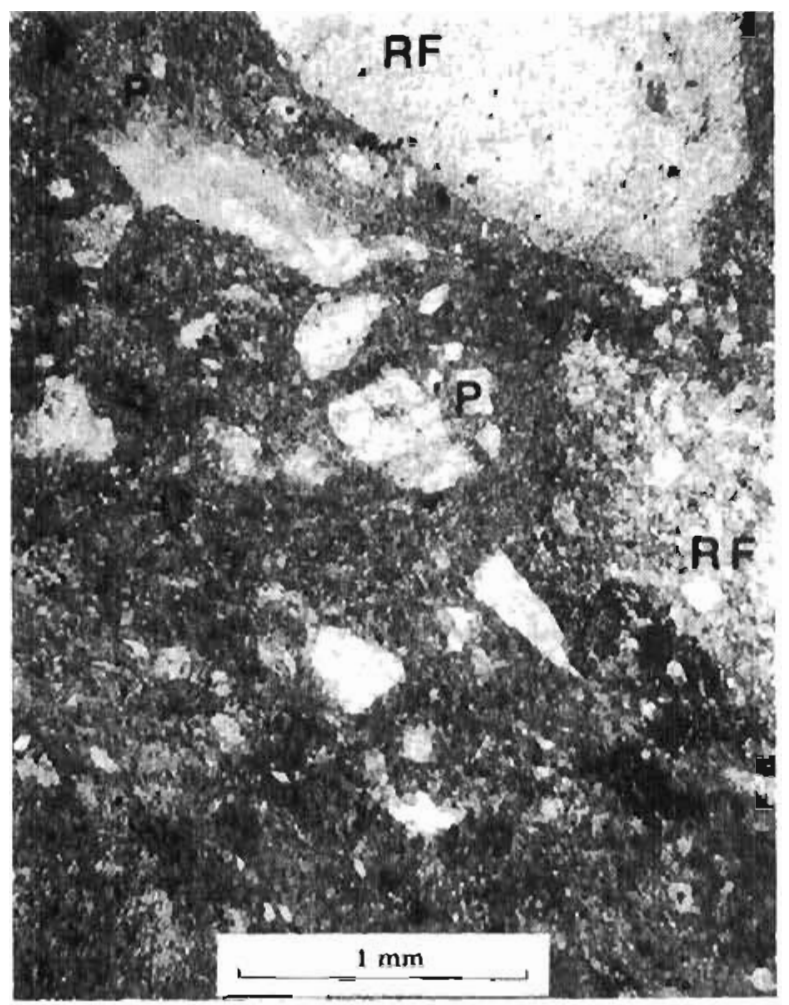

Figure 9. Photomicrograph of volcanic agglomerate from the Tangle Lnkes Formation. Large volcanic rock (ragments (RF) are imbedded in a volcaniclastic matrix consisting of plagsioclase phenocrysts (P), smaller volcanic debris, and possibly devitrified glass.

'Table 4, Mosies of reprixtulatiuc specimens from the Amplitheoler Group

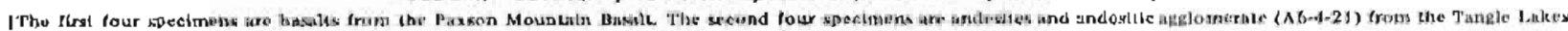

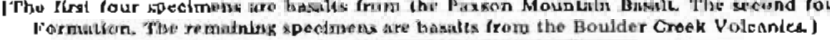

\begin{tabular}{|c|c|c|c|c|c|c|c|c|c|c|c|c|c|c|}
\hline \multirow[t]{2}{*}{ Spocimon No. } & $B A \cdot 3-1 /$ & $B A \cdot 3-12$ & NS-260 & JS.261 & $A 5-1-21$ & JSP: $\mathbf{3}$ & $A 6.4 \cdot 20$ & A5-8.21 & A $6 \cdot 8 \cdot 4 \mathrm{~A}$ & $A E-Y-4 B$ & $A 5 \cdot B-40$ & $A G \cdot 8.12$ & $A S-4-25$ & A5-8-1 \\
\hline & \multicolumn{14}{|c|}{ Modes } \\
\hline Aclinolite & & - & - & - & - & - & - & - & . & - & - & - & - & 20 \\
\hline Culerto & & 3 & - & . & - & 3 & $?$ & - & . & . & . & . & 2 & - \\
\hline Chlorilo & 25 & 10 & 5 & 6 & - & - & 10 & - & 5 & & - & $\cdot$ & 10 & 20 \\
\hline Epidote & 10 & 7 & 10 & 10 & . & $\sqrt{3}$ & $\cdot$ & 10 & 16 & 5 & i & 12 & 2 & 2 \\
\hline Homatik & 3 & E & - & $\cdot$ & $\cdot$ & $\cdot$ & . & - & - & - & - & $\cdot$ & $\cdot$ & - \\
\hline Mmenilet & · & - & 1 & 2 & - & - & - & - & - & . & $\cdot$ & $\cdot$ & - & - \\
\hline Magnelike! & 2 & 5 & 2 & 3 & - & 2 & 2 & . & $y$ & 12 & 10 & 10 & 3 & $s$ \\
\hline Opnque malcrial & 10 & 10 & - & - & 35 & $B O$ & 10 & 15 & 12 & 30 & - & - & - & - \\
\hline Plagloclese2 2 & 40 & 30 & 65 & 60 & 5 & 20 & $\cdot$ & 20 & 30 & 20 & 30 & 30 & 30 & 15 \\
\hline (An content) & $<\mathrm{B}$ & $<5$ & 50 & 5.40 & $<5$ & $<5$ & . & 5.15 & $<5$ & $<5$ & $<5$ & $<5$ & $<\bigsqcup$ & $<5$ \\
\hline Prohnils & E & $\cdot$ & - & - & $\cdot$ & $\cdot$ & · & $\cdot$ & $\cdot$ & $\cdot$ & : & $\cdot$ & $\cdot$ & $\cdot$ \\
\hline Pumpellylte & Б & - & - & - & - & 3 & 30 & • & • & 3 & 3 & 3 & 10 & $\cdot$ \\
\hline Pyroxone & - & 30 & 25 & 30 & - & 2 & 15 & 60 & 30 & 30 & 40 & 45 & 10 & 35 \\
\hline Quartz & - & $\cdot$ & $\cdot$ & - & 10 & 6 & - & E & $\cdot$ & $\cdot$ & 3 & $\cdot$ & 3 & - \\
\hline $\begin{array}{l}\text { Volcnnic rock } \\
\text { framonts }\end{array}$ & - & - & - & & 50 & - & & - & - & . & . & . & . & - \\
\hline
\end{tabular}

1 Plafioclase is albituzed and contsine secondary cpidole, sirricitc, and clay.

¿Commonly atlered to leucoxene mineruls and homatile. 
Triassic section near Windy Creek in the Clearwater Mountains. He describes "Randed slates, black slates, red-weathering slates or shales, graywackes or line tuffs, tuffaceous conglomerale..." that overlits a thick sequence o[ greenstone or hasalt.

At the very top of the Tangle Lakes formation is a distinctive pillow andesite that attains a maximum thickness of 1,500 feet. The pillows are superbly developed (figs. 11, 12\} and provide posilive evidence for the submarine origin of the rocks. Nested pillows in several localities were sufícienlly well developed that stratigraphic 'Lops' could be determined. 'I'he atlitudes in each case are consistent with the Amphitheater syncline. Elsewhere in the Amplitheater Group, pillows are not as easily recognized because of severe joinling and lichen growth. Only a lew hundred leet along. strike from the outerop of figure 11, the pillows can be discerned only with difficully becalse of the pervasive jointing.

The lop of the pillow andesite member is taken as the upper contact of the Tangle Lakes Formation. There is

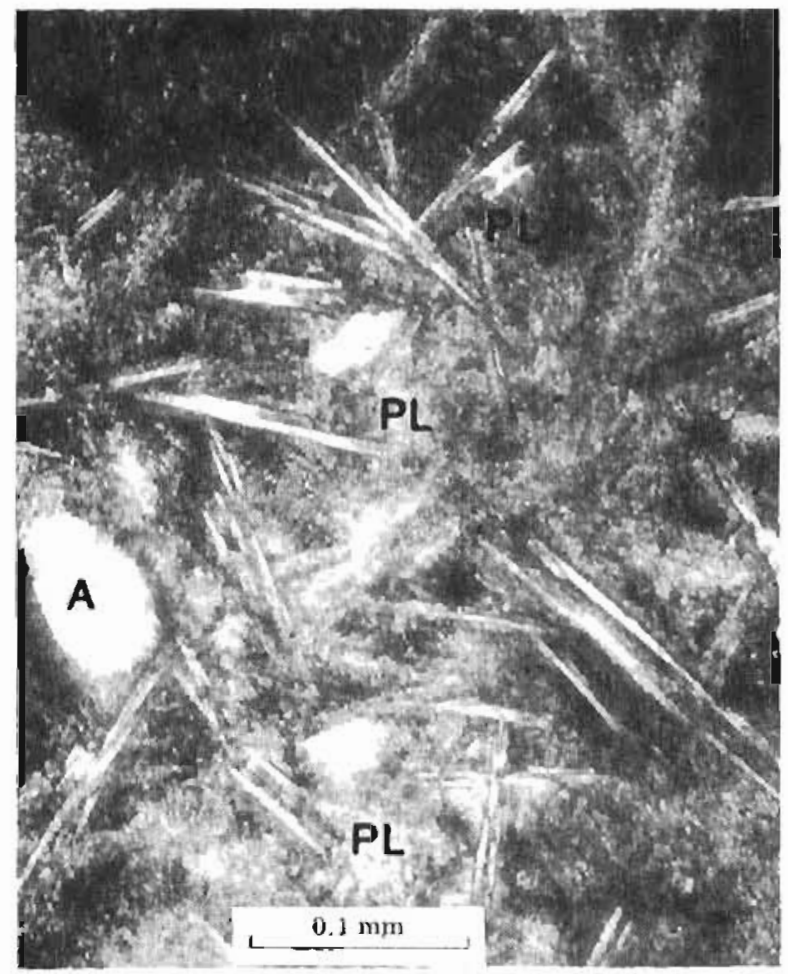

Figure 10. Photomicrograph of fine-gramed andesite flow showing small laths of plikgioclase (PL) with sivallowtail morphology. Aphaniti. hroundmass is mosily opaque malerial, probably devilification products. Tiny amygdules (A) are filled with radiating pumpellyite necdles. a sharp contact with overlying pillow basalt, the basal mermber of the Boulder Creek Volcanics. One or two thin (less than 200-Pool-thick) pillow basalts do occur irnmediately below the pillow andesite member on the north side of the Amphitheater syncline, but cannot be traced in the field for more than a few hundred feet.

\section{BOULDER CREEK VOLCANICS}

The type locality of the Boulder Creek Volcanics is in the low mountains just north of Boulder Creek and Sevenmile Lake 2 in the west-central part of the map area (pl. 1). There, npproximately 18,500 feet of interlayered green basalt and amygdaloidal basalt is exposed above the pillow andesite member of the Tangle Lakes Formation. These outcrops lie in the northem limb of the Amplutluater syncline. The section is present, but nol as well exposed on the south limb of the syncline north of Glacier Lake and the Denali High way.

Because of the low-angle plunge of the Amphltheater syncline to the west, even higher portions of the Boulder Creek Valcanics should be exposed west of the Maclaren River. The thickness stated above should thus be considered minimal.

The predominant lithology in the formation is a green to olive basalt that bears striking similarities to the upper portion of the Paxson Mountain Basalt. Amyg. daloidal zones, however, are much more common in lhe Boulder Creek Volcanics and locally attain thicksesses of nearly 3,000 feet. They are mapped as separale members on the geologic map of the area (pl, 1). These differences and the overall continuity of the Paleozoic and Mesozoic sections on the limbs of the Amplitheater syncline demonstrate that the two predominantly basaltic formations are different. Minor differences exist in the petrography of the rocks (lable 4), but at this time they cannot be used as distinguishing criteria.

The amygdaloidal members are the most distinctive in the formation nnd are critical to defining the folded structure of the rocks in the westem part of the map area. The rocks consist of alternating layers (fig. 13) of varying bulk cliernistry. This is apparent from the variation in concentration of amygdules, their size, and their nineralogy. Some layers only a lew inches thick consist of 75 percent amygdules, whereas adjacent layers of the same thickness may have less than 10 percent. Single amygdules range up to an incls in diameter and may be sparsely distributed through the rock. Thinsection examination (table A) shows their mineralogy to consise of epidote, quartz, pumpellyite, chlorite, prelinlte, and calcite.

The origh of the amygdaloidal basalts is somewhat

${ }^{2}$ Scuenmile Luke has baen known by the lacal residents for many years as Boulder Lake. Boulder Creek dradrs west into the Maclaren River. 


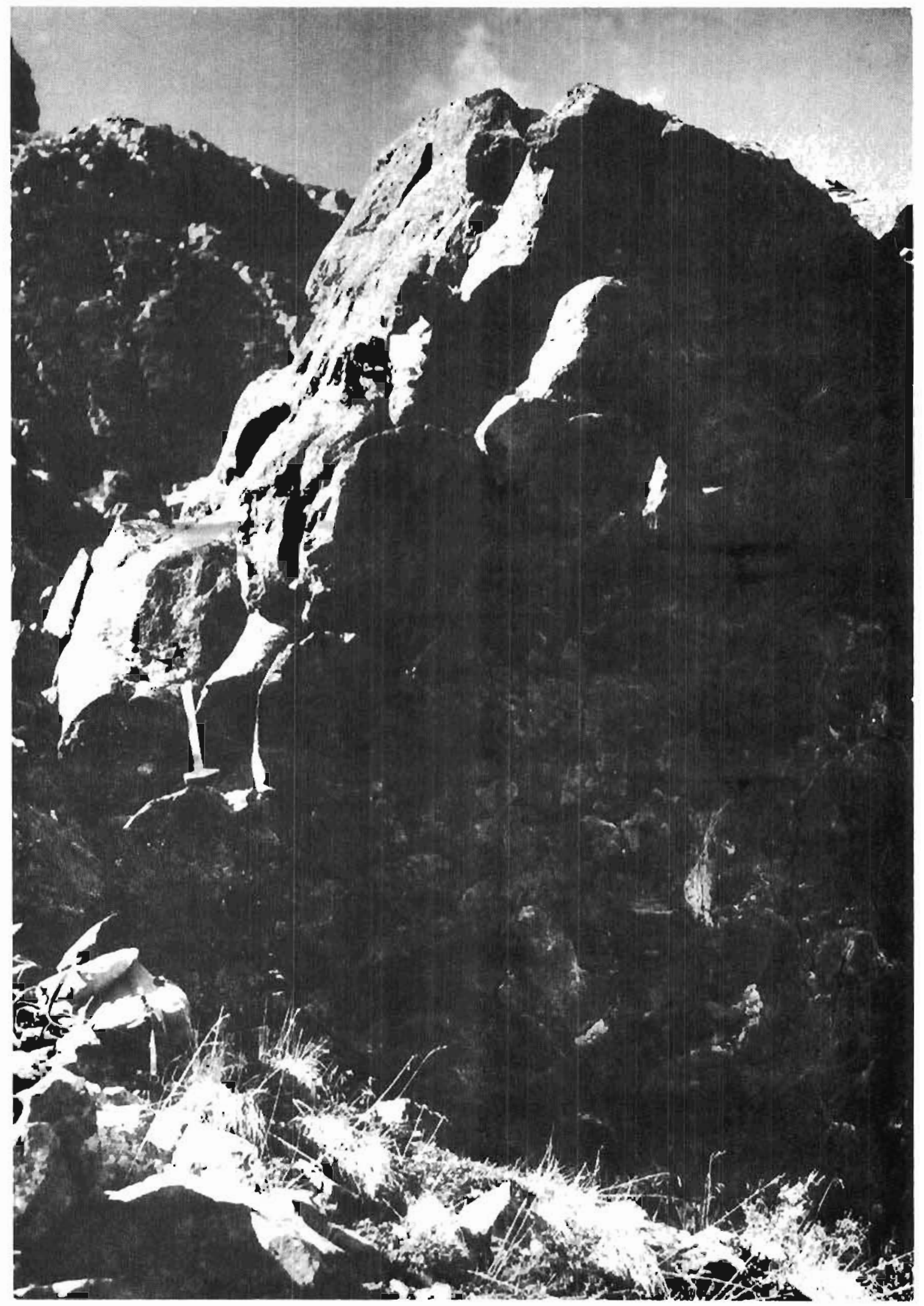

Figure 11. End view of woll-developed pillows in andesite of the Tangle Lakes Formation. Tops are to the lefl. 


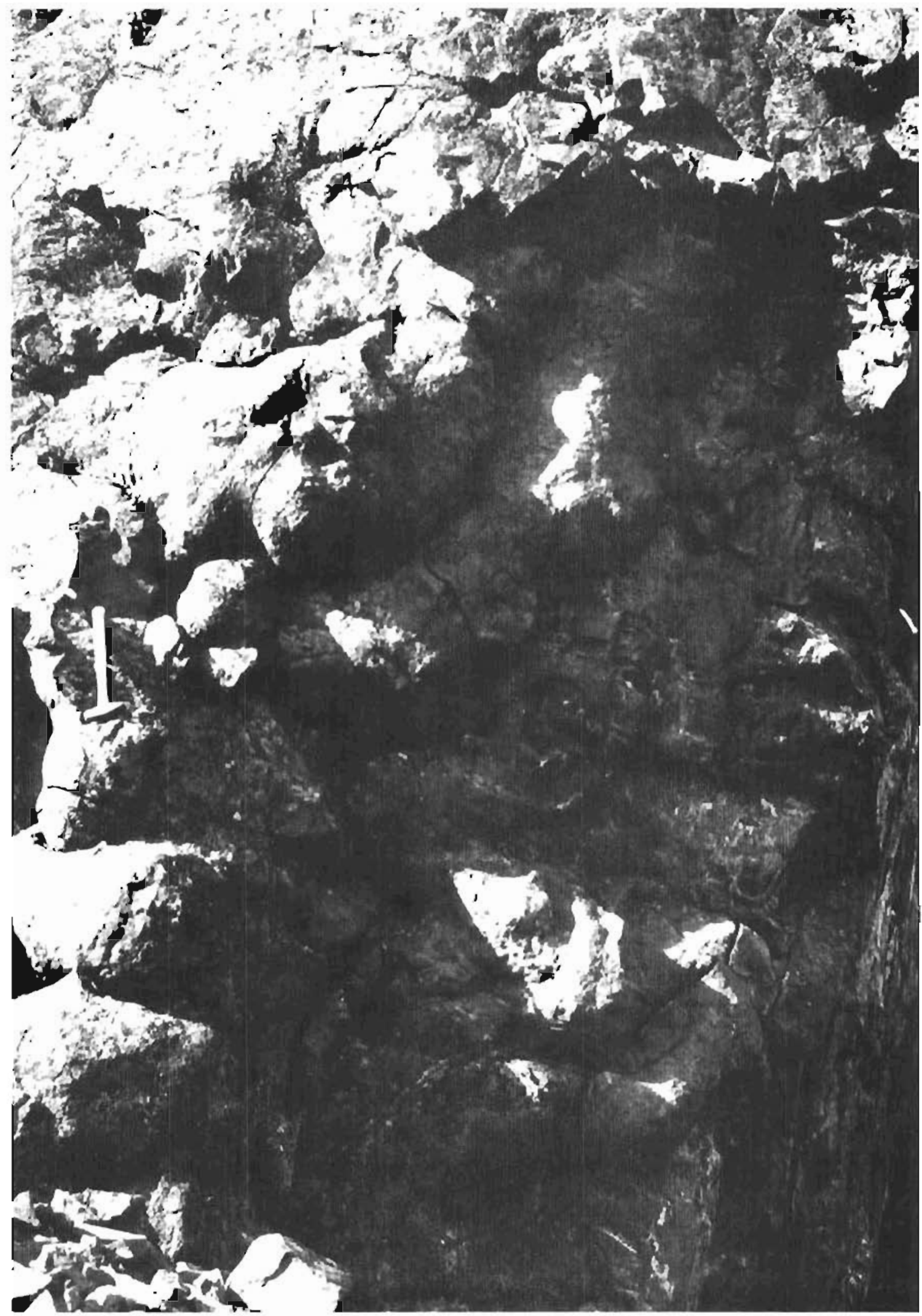

Wigure 12. Lonfitudinal view of pillow tubes in andesite of the Tangle Lakes Formalion. 


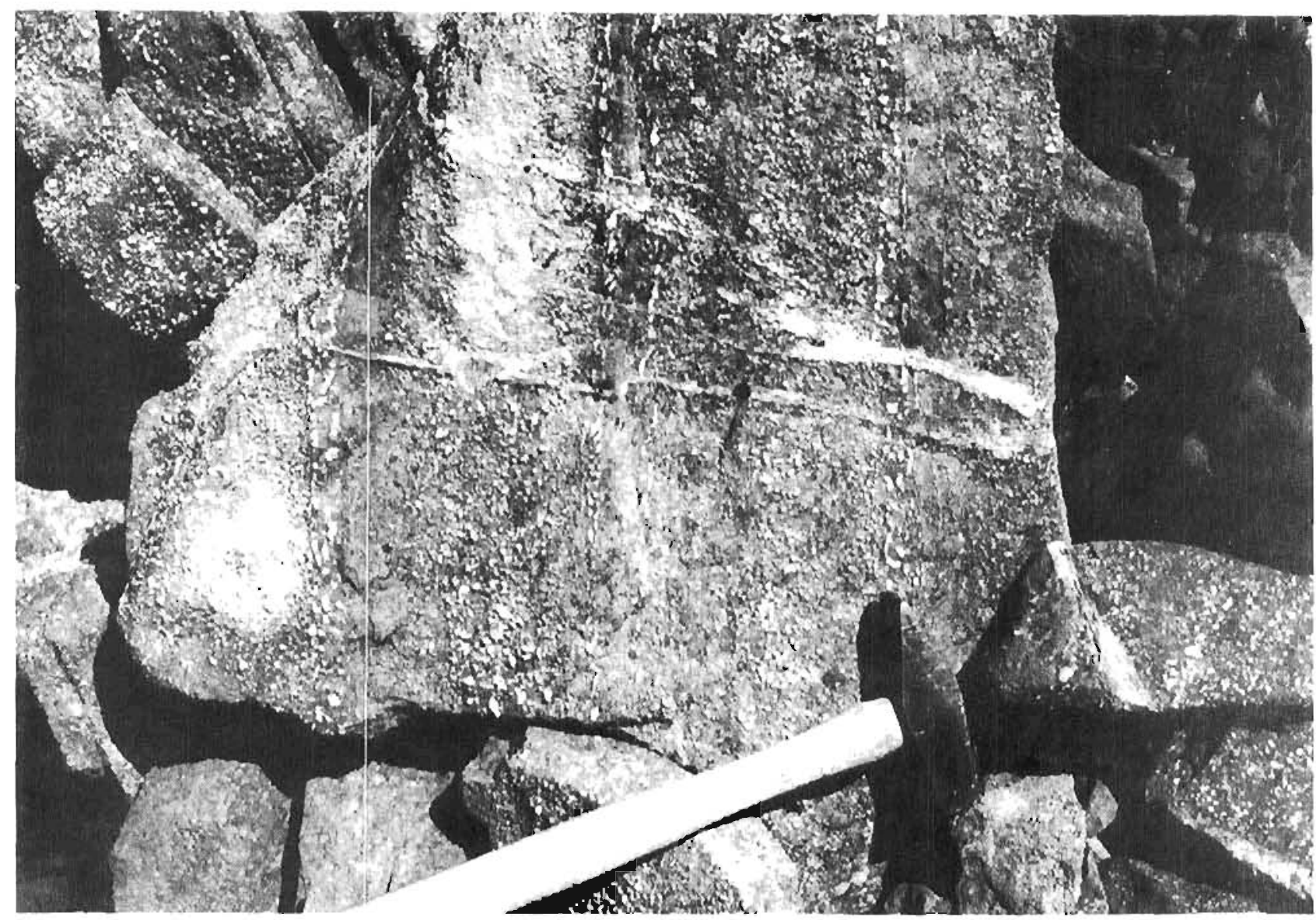

Figure 13. Typical layering of amygdaloidal flows within the Boulder Creek Volcanics. Amygdules may be equi. dimensional or elongute parallel lo bulk compositional layering. Late veinlets of epidote and quart\% are common.

problemalic, particularly with respect to their remarkable layering. Individual layers unly an inch thick can be traced in the lield lor over 100 feet without any detectable deviation in attitude. These must represent highly vesiculated individual flows that were capable of flowing with little resistance. Commonly, individual amygdules will be stretched out parallel to the primary layering (fig. 14), which may indicate how during cooling from magmatic temperislures. The only instance where amygdules are elongated normal to flow surfaces is near the chilled rinds of pillows found at the base of the formation.

\section{JURA-CRETACEOUS METAMORPHIC ROCKS}

A progressively metamorphosed and highly deformed sequence of argillite, graywacke, volcanic nows, and minor conglomerate of Jurassic and probably Cretaceous age are exposed north of the Broxson Gulch Thrust fault (pl. 1). Where observed as part of this study, these rocks--even in their lowest grade portion-are nolice- ably more deformed and recrystallized than any of the older sedimentary and volcanic rocks previously de-

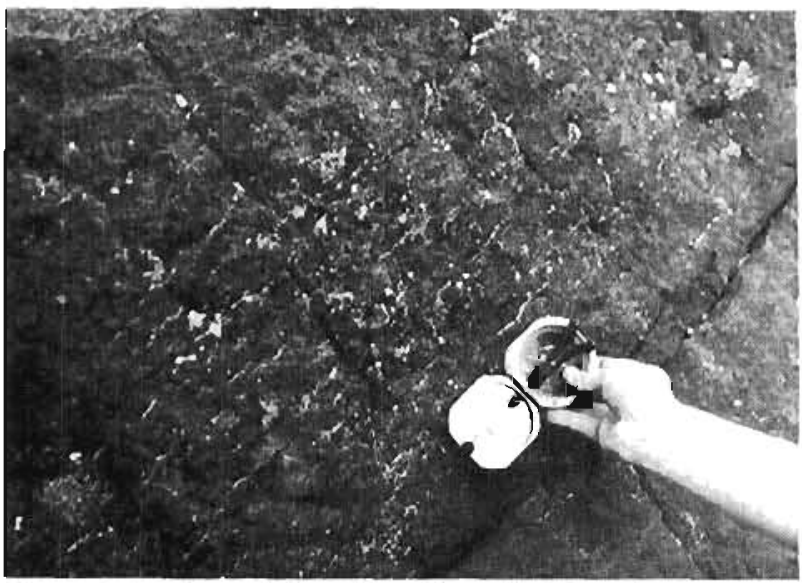

Figure 14. Amygdules aligned parallel to primary compositional layering in the Boulder Creek Volcanics. 
scribed. The rocks occupy a linear belt extending from the region west of the Susitna River (fig. 2) to the Delta River, where it is truncated by the Denali Faull (Sloul, 1972). Because of this unique cliaracter and history, they are now referred to as the Moclaren melamorphic bell (Smith, 1970a,b).

Only the lowest grade porlions of the Maclaren melamorphic belt are exposed in the present study area. Along the northern margin of plate 1 , greenschist and phyllite are the predominant lithologies. Thin-section examination (Lable 5) reveals that the parent volcanic fows or tuffs and argillaceous sediments have re. crystallized in the chlorite zone. The low-grade rocks are inlensely deformed, however. Isoclinal folds on the scalc of liand specinens and on the scale of 1 mile have been observed. Axial surlaces and metamorphic foliation dip uniformly to the north.
Maclaren River (pl. 1) is part of the Broxson Gulch Thrust. The evidence for estimating the magnitude of displacement along the thrust is discussed on pages 28 . 29, but it is highly probable that the structural dis. continuity extends west to the Clearwater Mourtains

The comfirmatory evidence for al least a Jurassic age of the pelitic sediments is provided by a new Jurassic fossil locality (Smith, 1974a) north of the tectonic contact in the Clearwater Mountains. The fossils are reportedly Upper Jurassic and from conglomerate beds in the low-grade portion of the Maclaren metamorplic belt. Similar conglomerates with interbedded, unfossiliferous linestone occur in the present study area just east of the Maclaren River, where they are overlain by the more common black phylljies and greenschists.

Detailed studies by Slout (1974) within the Maclaren terrane near the Delta River indicates that the de.

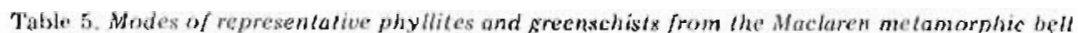

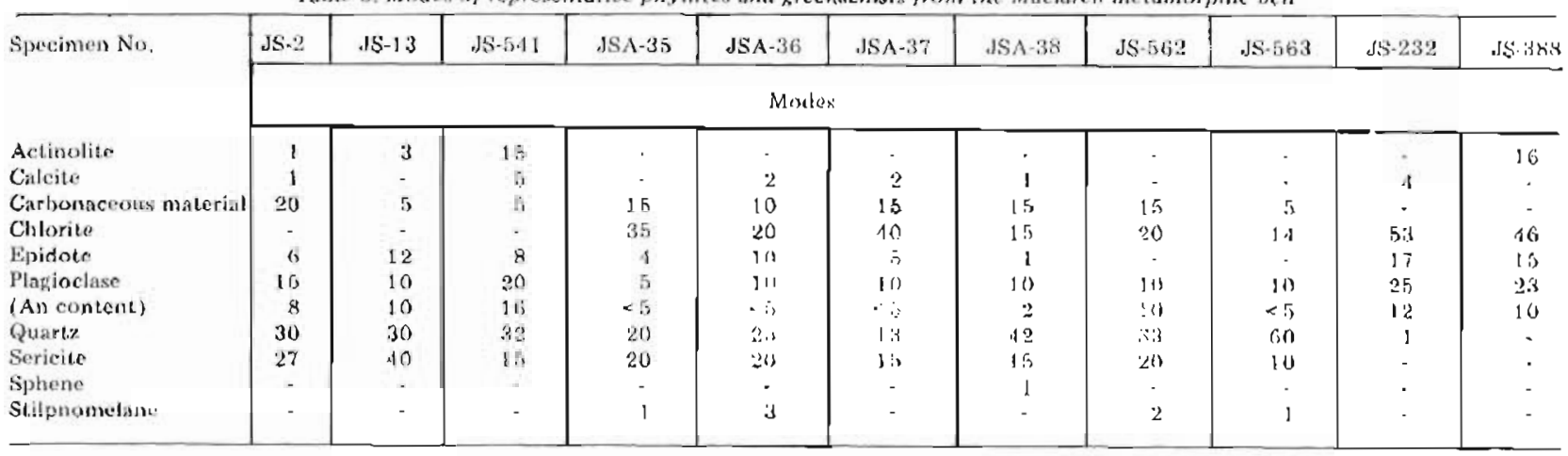

Beyond the northern boundary of the map area, the greenschists and phyllites are progressively metamorphosed to calc-magnesian gneisses and pelitic schists or gneisses, respeclively (Stout, 1965, 1974). The highest grade gneisses are in the siblimanite zone at the eastem and of the belt, but are in the kyanite zone at the western end (Smith, 1970; Smilh and Turner, 1973). Erratics of coarse-grained sillimanite gneisses derived from the high-grade portion of the belt are common in the glacial outwash along Eureka Creck and even south of the Amphitheater Mountains.

'Tlie depositional age of the metamorphic rocks is Jurassic and possibly Crelaceous. Stoul (1965) and Rose (1965, 1966) originally considered them to be preDevonian because of their high rank of metamorphism (compared with older rocks in the Alaska Range). Smilh $(1970,1971)$ concluded that the pelitic sediments were younger than the middle Eate Triassic Amplii. theater Group that they apparently overlie, but older (at least in part) than a Late Jurassic alkali gabbro that intrudes them. 'T'lo nature of the Triassic-Jurassic contact in the Clearwater Mountains is now in doubl (Smith and Turner, 1973) as a result of continued mapping since 1970. The contact in the vicinity of the positional thickness of the argillaceous sediments is over 15,000 geet. Because the Late Jurassic conglomerates are near the base of the section, this thick sequence of predominantly marine strata' is believed to be younger. Comparison with late Jurassic and younger rocks of similar composition elsewhere in Alaska strongly suggests a correlation witl the Gravina-Nutzolin belt (Berg and others, 1972). This beit, located in the eastern Alaska Range, is approximately 20,000 feel thick and consists mainly of dark-gray argillite, siltstone, graywacke, and conglomerate in its lower part, overlain by andesilic fragmental rocks and nows of the Clyisana Formation (Richter and Jones, 1972). The rhythmically allernating graded beds of gray to darkgray argillite, siltstone, and graywacke that constitute the major part of the lower part of the section correlate well with the banded phyllites shown in plate 1 . Despite the strong axial-plane cleavage developed in these low-grade rocks, the graded bedding is remarkably well-preserved.

The age of the Gravina-Nutzotin belt in the eastern Alaska Range is from Late Jurassic (Oxfordian) to Early Crelaceous (Barremian) (Berg and olhers, 1972). These ages are consistent with the Late Cretaceous-Early 
Tertiary melamorphic age of the Maclaren metamorphic belt, independently determined by radiometric dating techniques (Smith and Lanphere, 1971; Smith and Turner, 1973).

\section{TERTIARY ROCKS}

Conglomerate, coal-bearing sandsione, and shale of probable Late Oligocene and younger age are found in scattered outcrops throughout the Eureka Creek area. Moffil (1912) first described the Tertiary sediments near the Delta River as the weslem extension of Mendenhall's (1905) Gakona Formation. The rocks are in general poorly exposed owing to their easy erosion and to the extensive cover of younger glacial drift. In this study, the distinction between the 'Tertiary deposits and the lithologically similar Quaternary deposits is based on the degree of consolidation and association with coal-bearing sandstones. The Tertiary conglomerates are poorly to well consolidaled, whereas the overlying gravels of presumed Quatemary age are generally unconsolidated deposits.

The Tertiary sediments in the region have not been sufficiently studjed to establish the stratigraphic re. lationships between the various lithologies. The lowermost beds in the section are usually coarse-bedded conglomerales that unconformably overlie all older rocks. But at several localities (pl. 1) on the flanks of the Amphitheater Mountains, a fine-grained olivine basalt is the lowermost rock. It lypically occurs in light-colored, frost-heaved oulcrops that are easy to overlook. Ex. amination of a single thin section shows 10 percent olivine phenocrysts embedded in a line-grained ground. mass of 70 percent labradorite (An65), 10 percent calcic clinopyroxene, 7 percent euhedral magnetite, and 3 percent dark-brown biotite (fig. 15).

The basal conglomerates are usually interbedded with coal-bearing sandstones. A notable exception is 2 miles east of the outwash plain of the West Fork Glacier, where at least 100 feet of dunite conglomerate un. conformably overlies the Permian upper Tetelna Complex. Moffit (1912) first noted the outcrops because of the huge landside on the east slope of the mountain. It contains blocks of conglomerale up to 25 feet in diameler. The rock consists of coarse conglomerate (fig. 16) with up to 90 percent dunite cobbles and bouklers interbedded with coarse sandstone. Cobbles of granodiorite, porphyritic volcanic flows, and siliceous tuff are found in subordinate amounts. Thin-section examination ol three sandstone specimens (fig. 17) shows serpentinized olivine grains wilh occassional grains of compositionally zoned plagioclase, microcline, clinopyroxene, and spinel.

Withouk exception, all of the clasts observed in the conglomerate and sandstone can be identified with a local source area. In particular, the dunite cobbles and olivine and spinel grains must be derived from the dunite

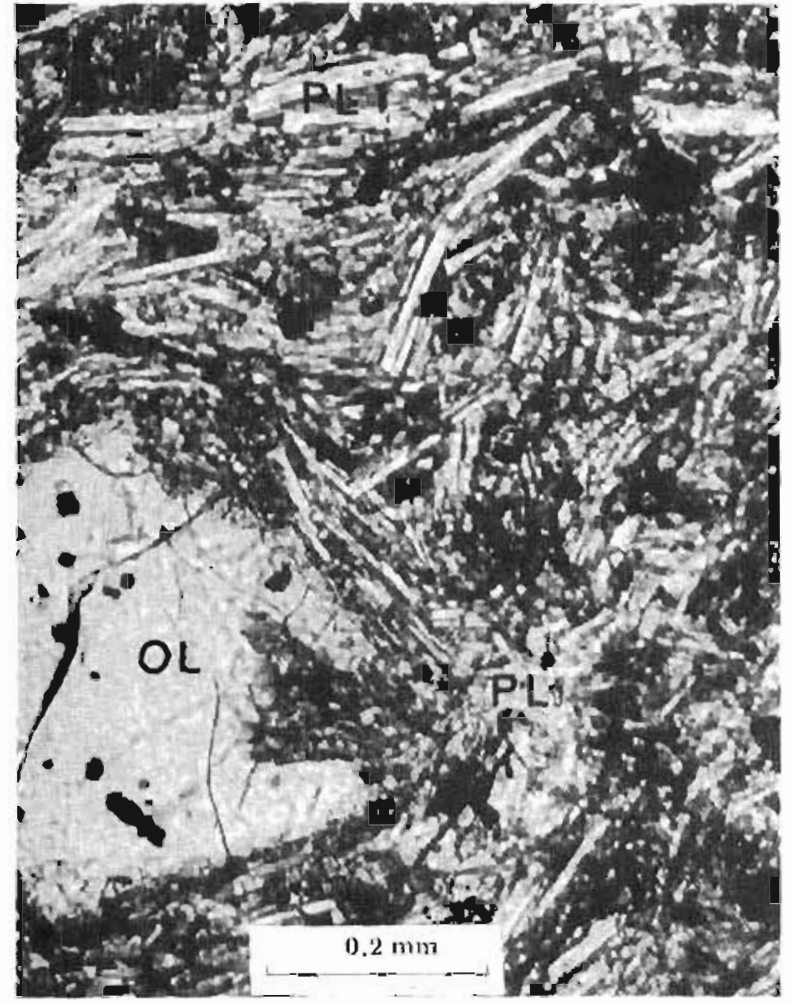

Figure 15. Pholomicrograph of porphyritic olivine basalt of Tertiary agc. Olivine phenocrysts (OL) are embedded in a line-grained grounclmass of labradorite (PL), magnetite, und elinopyroxene.

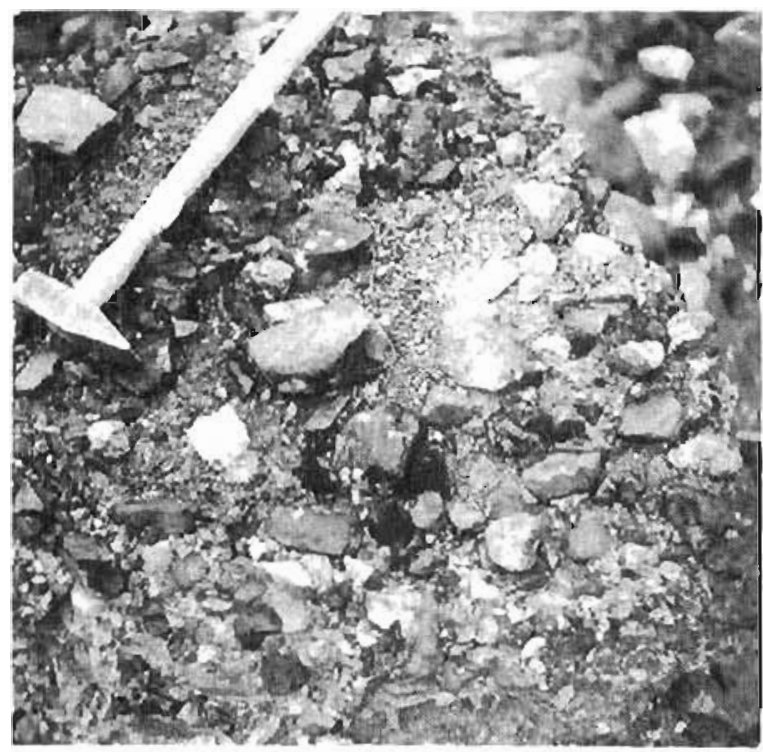

Figure 16. Dunite conglomerate in autcrop east of Broxson Gulch. 


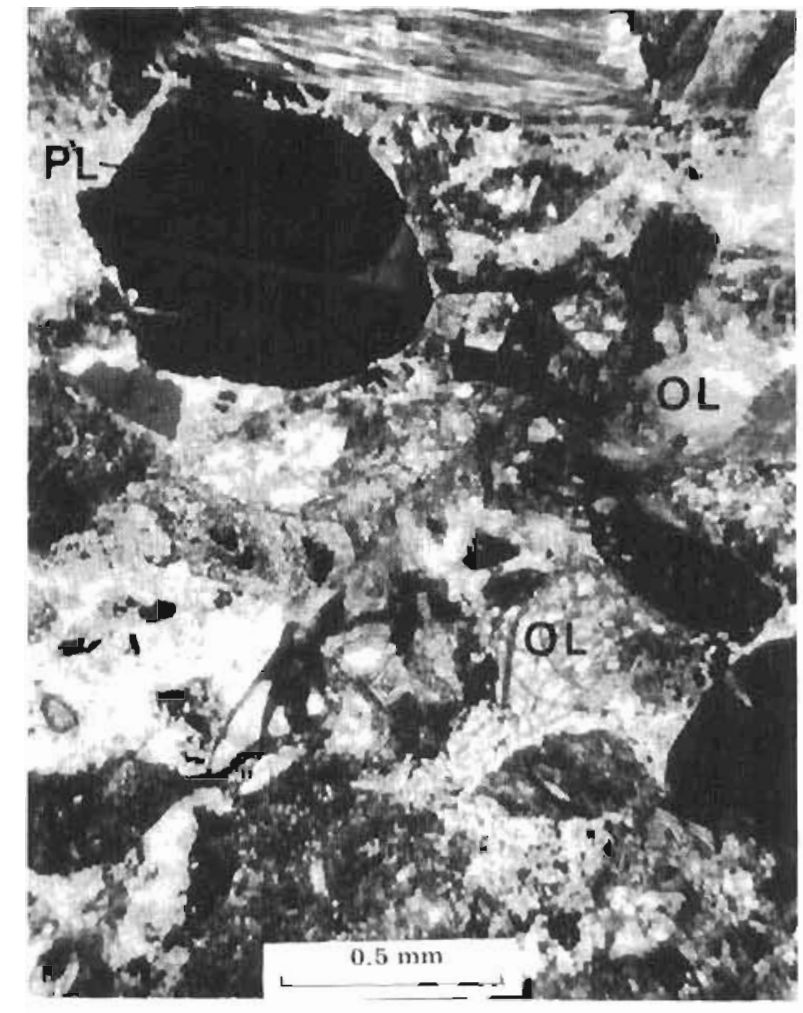

Fisure 17. Pholomicrograph of coarsc sandstone interbedded with dunite conglomerals near Broxson Gulch. Serpentinized olivine grains (OL) and zoned plagioclase (PL) derived from nearby granodiorite are prescnt.

bodies (pl. 1) that are found only along the Broxson Crulch Thrust, less than 1 mile away. The granodiorile cobbles and feldspar grains have compositions identical with nearby granodiorite intrusives. The remaining volcanic rock fragments could easily be derived from the underlying Tetelna Complex.

A notable exclusion from the suite of clasts ane melamorphic rock types from the Maclaren meta. morphic belt. The latter rocks are well exposed in the southern drainage of the Alaska Range; in fact, pebble: and cobbles of most metamorphic lithologies are abun. dant in the present-day stream gravels that pass over the older conglomerates. A diligenl search was made of each of several conglomerate outcrops extending from Ann Creek (near the Delta River) to Broxson Gulch, and not a single clast of Maclaren bett rock was found. $A$ possible interpretation is that the Maclaren metamor. phic belt was faulted into its present position after the conglomerates were deposited (p. 28).

The precise age of the Tertiary beds is still proble. matic owing to the lack of detailed studies on the well-preserved flora. Plant megafossils collected from the coal-bearing sandstones between Broxson Gulch and the
Wesl Fork Glacier are currently being studied by J.A. Wolte of the U.S. Geological Survey, but as of this writing, no rinal conclusions had been made. A diverse conifer hora seems to be represented, and may include Melasequoia. Other Corms resembling Alnus evidens (Holl.) are also present and are suggestive of a Late Oligocene age (Wolfe, 1966, 1972).

A Late Oligocene or younger age for the Tertiary rocks is further suggested by the absence of older Terliary rocks elsewhere in the Alaska Range. The base of the Tertiary near the Nenana River is the Healy Creek Formation, which is no older than Late Origocene (Wahrhaftig and others, 1969). This formation is apparently correlalive with approximately 2,000 feet of poorly consolidated sandscone, shale, and coinglomerate will numerous interbedded coal layers in the Jarvis Creek coal lield (Wahrhaftig and Hickcox, 1955). These rocks are on the northern flank o[ the Alaska Range and unconformably overlie the pre-Pennsylvanian(?) Birch Creek Schist terrane.

\section{QUATERNARY DEPOSITS}

More than 50 percenl of the Eureka Creck area is covered by glacial till, oulwash, and related deposits. Most of this is ground moraine that forms a rather uniform veneer over the glacially scoured bedrock below. These deposits consist of unconsolidaled, unsorted glacial debris, mostly gravel. Where the deposits overlie poorly consolidated conglomerates of possible Tertiary agc such as around Fielding Lake (pl. 1). incorrecl age assignments may be easily made.

Unconsolidated to poorly consolidated sands and gravel of problematic age are exposed along the banks of Eureka Creek. The unit weathers to a distinctive orange and forms impressive hoodoos in several localitics. The unit is well bedded and las a horizontal allitude except near underlying bedrock. In such cases, the bedding conforms to the bedrock Lopography.

In the second drainage east of Broxson Gulch (pl. 1), similar but helter consolidated gravels contain abundant lignite and partially coalificd wood. The relatively lightweighl, woody character of these organic layers suggests that they are younger than the Tertiary conglomerales and associated black coal seams. Al this locality, the beris dip north at 15 degrees and are unconformably overlain by 3 feet of gray unconsolidated till.

A distinctive morainal topography characterizes all ol the valleys on the south side of the Alaska Range that now have active glaciers. T'he lateral moraines are lhe most obvious, and can extend for several miles beyond the present ice front. Ponds dammed by terminal moraines are present at the terminus of the Easl Maclaren Glacier.

A widespread bul more subdued morainal topography provides abundant evidence for an earlier, more ex- 
tensive glaciation. Beautiful U-shaped watergaps in the Amphitheater Mountains with terminal lobes that close to the south demonstrates that in probable Wisconsin time an ice sheet extended from the southern flank of the Alaska Range southward through and beyond the Amphitheater Mountains. The best evidence for the direction of ice flow is from the distribution of pelitic gnelss cobbles and erratics derived from the Maclaren metamorphic bett. This distinctive and unmistakable lithology has been observed in the glacial deposits all along the southern flank of the Amphitheater Mountains and as far south as Paxson Mountain (pl, 1). This suggests that Wisconsin ice in the Eureka Creek area found egress to the Copper River Basin to the south rather than through the Delta River valley to the north.

The periglacial environment of the region is also expressed by several well.developed rock glaciers (pl. 1). The largest of these, are on east-facing slopes near Lower Tangle Lake and Landmayk Gap Lake. They are generally several hundred feet wide and up to one-half mlie long. Their terminal regions are quite steep and up to 60 feet high.

Other Quatemary deposits of nole in the Eureka Creek area are landslides. Two in particular are impressive because of their areal dimensions and the house-sized blocks contained within them. Houseblock Valley, just south of the west end of Sevenmile Lake, is over 1 mile long and has blocks of basalt from the Boulder Creek Volcanics with dimenslons up to 30 feet.

The other locality is that described by Moffit (1912, pl. IVA) on a northern tributary of Eureka Creek near Broxson Gulch. This slide approaches 1 mile in its greatest dimension and is notable for its unusual blocks of dunite conglomerate (p. 19). Al the bottom of the hills, the blocks are overlain by extensive alluvial fans that originate on the opposite slope. Because the silde is unglaciated, its age is between the last Pleistocene advance and the present erosional epoch.

Alluvial deposits-mostly fans and aprons along the lower flanks of most ridges-and talus are distinguished on plate 1. Much of the bedrock in the Amphitheater Mountains is severely frost heaved, and in many in. stances the distinction between talus and bedrock is arbitrary.

\section{INTR USIVE ROCKS}

The intrusive rocks in the Eureka Creek are range in bulk composition from quartz monzonite to dunite. The known time span of the intrusive history is from $125 \mathrm{~m} . \mathrm{y}$. to approximately $30 \mathrm{~m} . \mathrm{y}$. (Smith and Lanphere, 1971; Smith and Tumer, 1973; Turner, personal commun., 1973). 'To facilitate their interpretation within the stratigraphic and tectonic history of the region, the intrusive rocks are discussed in two categories corresponding to the areas north and south of the Broxson Guich Thrust fault (pl. 1). Only one in- trusive rock-the dacite porphyry dikes-are belleved common to both areas. These are described in the region south of the Broxson Gulch Thrust (below) because of their greater abundance there.

\section{INTRUSIVE ROCKS SOUTH OF THE BROXSON GULCH THRUST FAULT}

Most of the intrusive igneous rocks in this region appear to be temporarily and spatially related. Rose (1966b) first studied these rocks and noted the preponderance of gabbro and mafic gabbro associated with dunites and peridotite near Fish Lake in the center of the map area (pl. 1). Rose also describes a few felsic varieties, including granite and leucogabbro. Geologic mapping as part of this study reveals that this suite of intrusive rocks defines a belt extending from the east side of the West Fork Glacier southeast through Fish Lake and on into the Amphitheater Mountains. There, the suite has a generally arcuate distribution that conforms to bedding trends in the Amphitheater syncline. Near Fourteenmile Lake north of the Denals Highway in the southeastern corner of the map area (pl. 1), the belt appears to swing around to the west. Isolated outcrops of dunite and perldotite on both sides of Tangle Lakes on the south limb of the syncline suggests that the trend continues to the west. In general, the rocks intrude both the Paxson Mountain Basalt and the Tangle Lakes Formation. The main body of intrusive rocks lie 'stratigraphlcally' between these two formations.

At its northwestem end, where the rocks are predominantly dunite, the belt appears to be truncated by the Broxson Gulch ThrusL fault system. At its southern and southwestern end, the belt is covered by glacial till. Because of their spatial and apparent genetic relationships, this suite of rocks will hereafter be referred to as the Fish Lake Complex.

The manic and ultramanic rocks of the Fish Lake Complex are typicaly exposed as brown to red rubble (fig. 18) on small hills usually isolated from outcrops of older host rock. Despite the poor outcrops, however, a crude compositional layering can often be detected, whlch suggests that the Complex is a differentiated layered sill. A preferred orientation of plagioclase laths in some gabbros-particularly near Fourteenmile Lake (pl. 1)-Purther indicates that the rocks were capable of flow during intrusion.

At least the gabbroic portions of the Complex were hot enough during intrusion to lacally bake the country rock. Near Eureka Creek, a tremolite-bearing skarn (fig. 19) is locally developed in the Tangle Lakes Formation, where it is in contact with the gabbro. Thinsection examination (table 6 ) of the skarn (specimen A5-7-1) reveals coarse tremolite laths up to 1 inch long embedded in a matrix of recrystallized calcite and graphite. The gabbro (specimen A5-8-31) contains ser- 


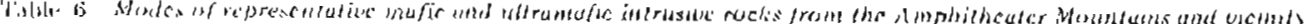

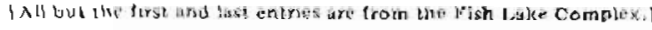

\begin{tabular}{|c|c|c|c|c|c|c|c|c|c|c|c|c|c|c|}
\hline \multirow[t]{2}{*}{ Sloushen No. } & $\lambda 5-7-1$ & A. 5.8 .31 & $A+-5-1$ & $A 4-5-2$ & A $4-5 \cdot 4$ & $A-5-5$ & A $1-6-11$ & A4-6-15 & $A 4.6 .16$ & A. $4.6-17$ & A4.6-1S & $A 5.0 .19$ & $15-4-27$ & $A-1-31$ \\
\hline & \multicolumn{14}{|c|}{ sluder } \\
\hline Nug.4. & $\cdot$ & 30 & 35 & 25 & 11) & $2 Z$ & 10 & 1,0 & 5 & 45 & 5 & . & .15 & - \\
\hline Biolut & - & $\cdot$ & & - & - & - & & 10 & $\cdot$ & $\cdot$ & - & 5 & - & - \\
\hline Cateite & .55 & & - & ' & $\cdot$ & & $\cdot$ & $\cdot$ & - & . & $\cdot$ & - & & $\cdot$ \\
\hline Chomespinel & $\cdot$ & - & - & - & $\cdot$ & - & - & - & 3 & - & 2 & - & - & - \\
\hline Hormbirmale & & $\cdot$ & 20 & 10 & - & ju & 30 & 3 & 2 & $\cdot$ & 5 & 5 & $\cdot$ & 25 \\
\hline N:innetile & 5 & 5 & 3 & . & 15 & 2 & v & 3 & 10 & 5 & 2 & $\cdot$ & $\mathrm{s}$ & $\overline{5}$ \\
\hline Microcline & & $\cdot$ & . & & $\cdot$ & $\cdot$ & $\cdot$ & $\cdot$ & - & $\cdot$ & $\hat{\wedge}$ & .10 & . & $\cdot$ \\
\hline Thlivisi: & - & $3<1$ & & - & - & - & & - & 40 & 311 & 70 & - & - & - \\
\hline 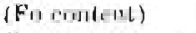 & - & $x(1$ & $\cdot$ & - & $\cdot$ & - & - & - & 90 & 88 & 85 & - & - & - \\
\hline 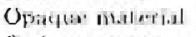 & [1] & & . & 5 & 5 & - & 10 & 4 & - & . & - & - & . & - \\
\hline Orwhosys roveste & & - & $\cdot$ & 20 & $\cdot$ & & - & - & - & - & . & $\cdot$ & - & . \\
\hline Plapelesedise & - & 361 & .10 & 40 & 10 & 60 & 20 & n & . & - & - & 冫 & - & - \\
\hline (An contrent) & - & ris̀ & 60 & 60 & $5 i$ & 60 & 10 & - & . & - & - & 20 & 50 & 70 \\
\hline Quarls & - & - & & $\cdot$ & & $\cdot$ & & $\cdot$ & - & - & $\cdot$ & 10 & 50 & 55 \\
\hline Sespentina & & $\overline{5}$ & 当 & - & - & - & - & 20 & .10 & 20 & $1 \bar{s}$ & $\cdot$ & $\cdot$ & $\cdot$ \\
\hline 'T'remolite & 30 & & $\cdot$ & & & & & & . & $\cdot$ & - & . & & . \\
\hline
\end{tabular}

pelllinized olivine, chrome spinel, saussuritized calcic plagioclase, and clinopyroxene.

An additional indication of the trmperature of intrusion is givers by Quick (1974), who sludied lhe partitioning of $\mathrm{Fe}^{+2}$ and $\mathrm{Mg}$ between olivine and spinel in the dunites exposed at Fish Lake. His results suggest an equilibration temperature of $450^{\circ}$ to $500^{\circ} \mathrm{C}$, which could be interpreted to indicate subsolidus intrusion or reequilibration during a later metamorphic event.

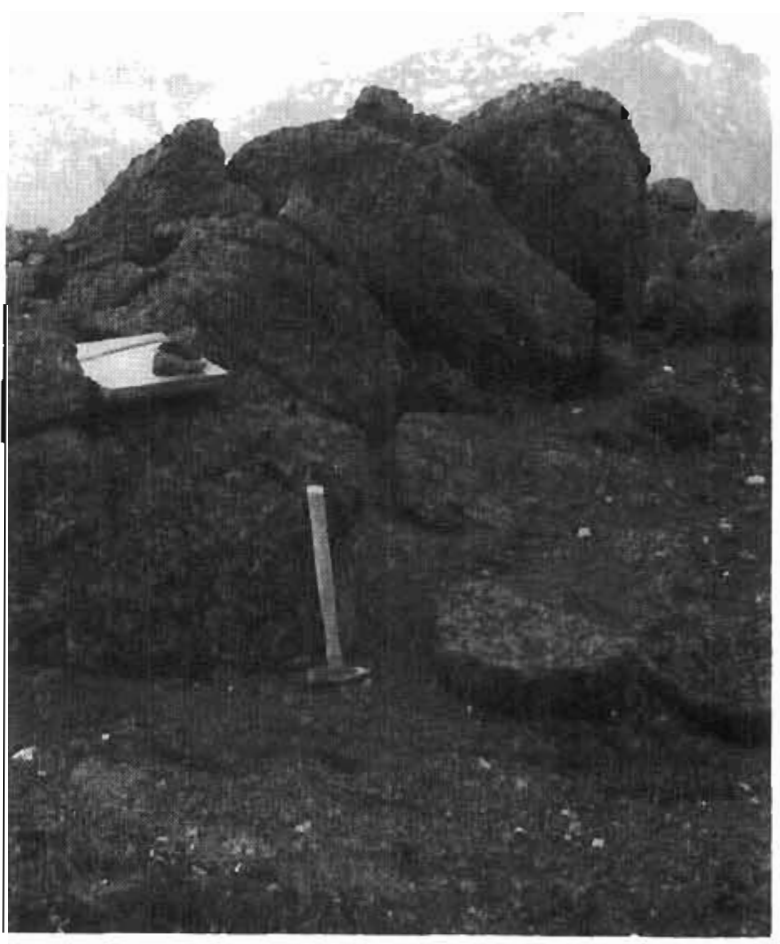

Figure 18. 'Typical outcrop surface of dunile and peridotile within the Fish Lake Complex.
The main body of dunite exposed in the low hills around Fish Lake consists of olivine (Fo80.90), secondary serpentine inunerals, and chrome spinel. Layering in this body seems to be clue in part lo variations in grain size and perhaps to differing degrees of serpentinization. Several distinct clinopyroxene-bearing lay.

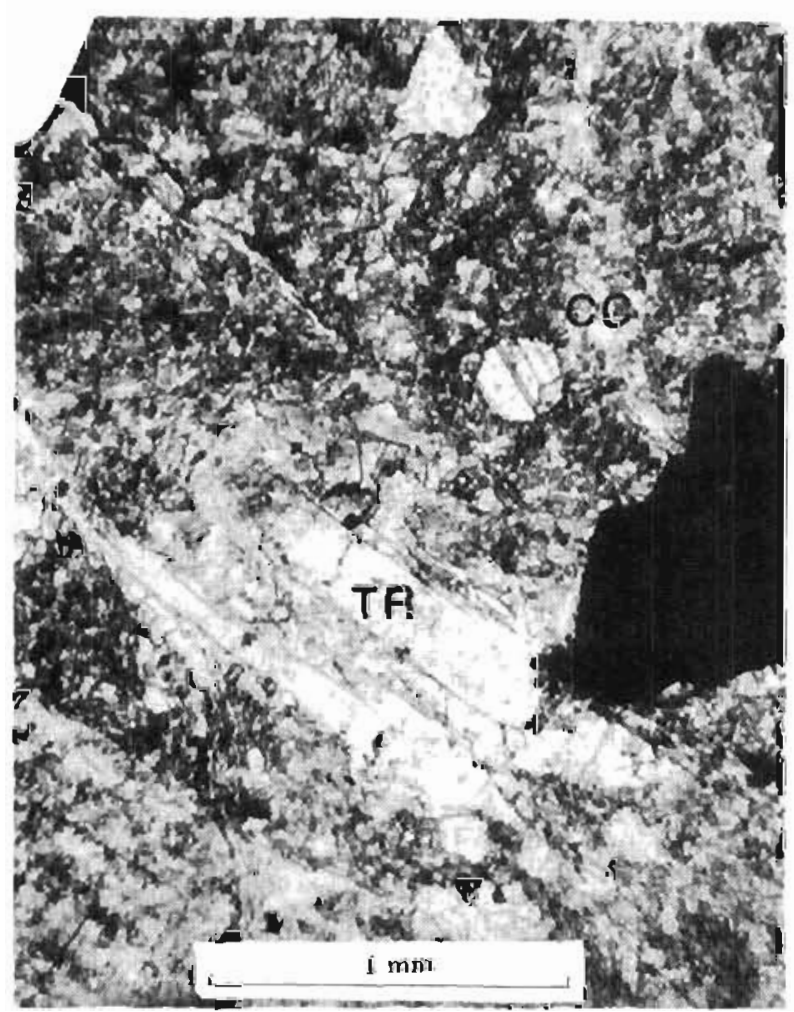

Figure 19. Photomicrogxaph of tremolite marble formed at the margin of intrusive gabbro 6 miles north of Sevenmile Lake. Euhedral irumolite laths (TR) and Iarge grains of recrystallized calcite (CC) are common. 
ers up to 12 inches thick wers noted, hnwever. There is little variation in mineralogy of the dunites for 15 miles between Fish Lake and the last exposures on the west side of the West Fork Glacier. The dunites elsewhere in the Complex (pl, 1) are less extensive and are more commonly associated with pyroxene-bearing varieties.

The dunites appeay to be least serpentinized in the central portions of the outcrops; some dunites there are virtually unaltered. Nearer the covered contacts, however, the dunite is commonly completely serpentinized. Hand-lens inspection of weathered surfaces clearly show subhedral grains of serpentine pscudomorphed after olivine.

Felsic intrusive varieties occur less commonly in the Complex, but are notable in the vicinity of Fourteenmile Lake (pl. 1). The low color index in some outcrops is due to secondary alteration of auglte to actinolite and the saussuritization of plagioclase. Quartz-bearing varieties (table 6) do occur, however, and could be derived as differentiates of a more mafic parent.

There are several satellutic dikes of gabbro intruded into the Tangle Lakes Formation that appear genetically related to the Fish Lake Complex. Specimen A5-4-27 (table 6) is typical. The dikes have a uniform northnorthwest trend and clearly cut across the primary composiltonal layering of the host rocks. The dikes range up to several hundred feet thick. At a locality 1 mile east of Lower Tangle Lake, a gabbro dike on the south side of Sugarloaf Mountain was followed continuously into a much more extensive body that is parl of the Fish Lake Complex.

The field relationships seem to indicate that the Fish Lake Complex is younger than the Late Triassic rocks they apparentiy intrude. There is some evidence, however, to suggest that the Complex was emplaced prior to the deformation that produced the Amphitheater syncline. The generally folded form of the main body of the Complex and the localization of the intrusive rocks along the contact between the Paxson Mountain Basait and the Tangle Lakes Formation are certainly suggestive of this. There is also the systematic variation in trend of the presumably related gabbro dikes that is suggestive of folding. North of Sevenmile Lake on the northern limb of the syncline, gabbro dikes and sils strike N. $70^{\circ} \mathrm{W}$., whereas in the vicinity of Lower Tangle Lake and Sugarloal Mountain, the dikes have a nearly noth-south trend. The age of lolding is problematic, but as discussed on page 55 , there is evidence that indicates it is possibly pre-Late Jurassic.

The minimum age assignment from field relationships is provided by the Tertiary deposits of probable Late Oligocene or younger age that appear to unconformably overlie the Fish Lake Complex. On the brosd rounded hills 4 to 5 miles north of Sevenmile Lake, the porphyritic olivine basalt described earlier overlies dunite and gabbro. On the hlll (elev. 4320) 1 mile east of the terminal moraine of the West Fork
Glacier, the projected dips of tertiary conglomerate, sandstone, and shale extend well above the Fish Lake Complex, which begins only one-balf mile to the south.

The only radiometric date that bears on the age of the Fish Lake Complex is a $125-\mathrm{m} . \mathrm{y}$. date on hornblende granodiorite (Smith and Tumer, 1973) in the Mt. Hayes A-6 quadrangle. The rock intrudes the Amphitheater Group and is clearly older than any intrusive rocks north of the Broxson Gulch Thrust fault. Any relationship between this body and the Fish Lake Complex can only be considered speculative at this time.

The only intrusive rocks south of the Broxson Gulch Thrust fault that are apparently unrelated to the Fish Lake Complex are dacite porphyry dikes. These bodies are numerous in the Amphitheater Mountains and are found along north-south-trending fracture zones (pl. 1); unlike the gabbro dikes discussed above, they show no variation in trend that could be attributed to folding.

The noteworthy fact about the dacite porphyry dikes is that they are found in the Jura-Cretaceous terrane north of the Broxson Gulch Thrust fault. They clearly cross-cut a massive dunite east of Broxson Gulch that is probably Tertiary. There, the dikes retain the north-south trend exhibited further south. Small boulders of the same rock were observed as part of the lateral moraines on the West Fork Glacier and on the glacier at the headwaters of Broxson Gulch, indicating that the dikes intrude the metamorphic terrane. At these localities, the dikes were nol found in place.

Petrogxaphically, the dacite porphyry dikes are quite distinctive (ng. 20). Two specimens were examined, one from near Landmark Gap Lake (A5-4-31) south of the Broxson Gulch Thrust fault and one from the west side of Broxson Gulch (B5.2-40) north of the thrust. The two rocks are identical (table 6 ). Botl are characterized by strongly zoned green to brown eubedral homblende phenocrysts up to $1 \mathrm{~mm}$ long. These are surrounded by strongly zoned plagloclase Peldspar laths interspersed with tiny magnetite octahedra.

There are at least two other north-south-trending dikes in the Amphitheater Mountains that bear similartiles to the dacite porphyry dikes. These occur in the small U-shaped valley just south of the east end of the Sevenmile Lake. Dike rock there has the same tiny homblende needles, but has strongly zoned plagioclase phenocrysts up to 0.6 inch in diameter.

\section{INTRUSIVE ROCKS NORTH OF THE BROXSON GULCH THRUST FAULT}

The intrusive rocks in this region include not only those north of the Broxson Gulch Thrust fault but aiso those that are intruded or faulted within the thrust zone itself. The rocks range from quartz monzonite to dunite, and trend east-west along the northern margin of the map area (pl. 1). Unlike the intrusive rocks south of the 


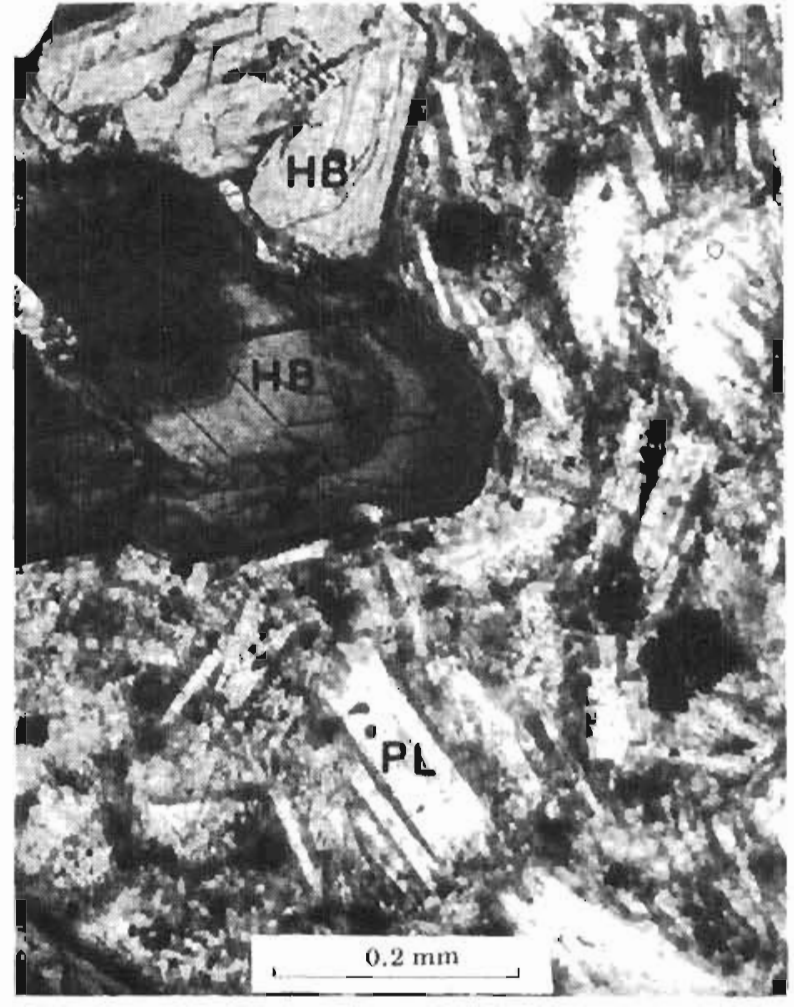

Figure 20. Pholomicroghaph of dikcite porphyry dike. Euludral roned hornblende (-IB) and roncel plafioclase phencerysts (PL) are combined wibin a ground mass of riner grained plugioclise, augiar, and mafí melitic.

Broxson Gulch Thrust lault, Lhey are post-latbe C're. Laceous, and in the case of the duniles, probably 'T'ertiary.

fieksic intrusive rocks, inainly quartz monzonite and granodiorile (Lable 7), underlie a considerable portion of the map area. 'lhe unvegelated pink-to orange-wealhered ridges between the Maclaren Glacier and Broxson Gulch consist of quartz monzonite. 'f'le rock is in- wensely sheared and altered hy secondary solutions, which have produced fracture [illings of oxidized pyrile and limonite lnoughout. The degree of alteration is so severe in some outcrops that the identily of the rock can be ascertained only with difficulty. Less-altered speci. mans (135-3-16 and B5-3-17, table 7) show in lhin section euhedral plagioclase grans up $103 \mathrm{~mm}$ diameler strongly altered lo sericite, epidote, and opaque clay minerals. Microcline is much less altered. Quartz is abundant and fresh, but lighly strained with sutured urain boundaries. 'The primary malic minerals, biotile and hornblende, are almost completely altered to chlorite, epidote, and opaque iron oxides. The amount of quarl\% and microcline are variable over the area mapped as quarty monzonite and locally, the rocks are pranodiorilic to quartz diorilic.

The contacts belween the quarl\% mon\%onite and the surrourding country rock am moderately well exposed. 'The soulhern contacl wilh Permian upper Tetelna Complex and 'Terliary conglomerate is a low'angle, north-dipping lorust faull that is interpreted as part of the Broxson Guldi Thress fault system. The and to orange staining so common in the altered quartz mon\%omte is well developed in the fault zone and in the adjacent andesitic volcaniclaslics and flows. 'The north. ern contact in two localities (pl. 1) is also a north. dipping thrusl fautl. Between tlue Maclaren Glacier and the East Maclaren Glacier, the quart\% monzonile is in l) rusl contact with phyllites of the Maclaren mela. morphic belt; just east of the East Tork Glacier the thrust contact is with serpentmized dunile.

In the norlseastem comer of the map area, a quartz monzonile slock exhibits intrusive conlacts with pelitic schists of the Maclaren melamorphic belt. Locally, there has been cuntact melamorphism of the previously metamorphosed Jura-Crelaceous sediments, and regional isograds predale the intrision (Stout, 1971). The quartz inonoznite here is lypically coarse grained and has no directud fabric. Inclusions of surrounding country rock are common (fig. 21). Thin-section examination (specimens JS.96, JS.36L A) reveal microcline, quartz, oligo-

Tilsle 7. Modes of representative felsic intrusive rocis north of und wilhen the Broxison Gulch Thrust fault

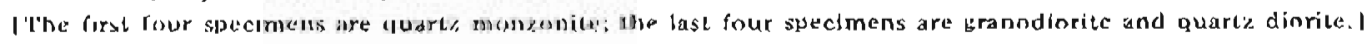

\begin{tabular}{|c|c|c|c|c|c|c|c|c|}
\hline \multirow[t]{2}{*}{ Specimen No. } & B.5-3-16 & 135.3 .20$. & JS-96 & $J S-361 A$ & B5-.3-17 & JS-241A & JS-386 & JS-51 \\
\hline & \multicolumn{8}{|c|}{ Morles } \\
\hline Biotite & - & - & - & - & . & - & - & \\
\hline ChJorite & 10 & A & 5 & 7 & - & 1 & 1 & 1 \\
\hline Epirlate & 2 & 2 & . & - & . & 1 & 1 & 12 \\
\hline Hornblende & & & - & - & 30 & 25 & 33 & 18 \\
\hline Microcline & 20 & 25 & $3 \sqrt{3}$ & .35 & - & 15 & 14 & - \\
\hline Opaque alleration & 1 & 5 & - & - & - & 7 & 14 & 35 \\
\hline Pláfioclase: & 30 & 30 & 22 & 25 & 60 & .33 & 25 & 6 \\
\hline (An contenl) & $2 \pi$ & 30 & 12 & 28 & 40 & 25. & 32 & 28 \\
\hline Quarlz & 35 & 35 & 37 & 25 & 10 & 16 & 2 & 23 \\
\hline Sericitc & 2 & - & 1 & 11 & - & 2 & 7 & 5 \\
\hline
\end{tabular}




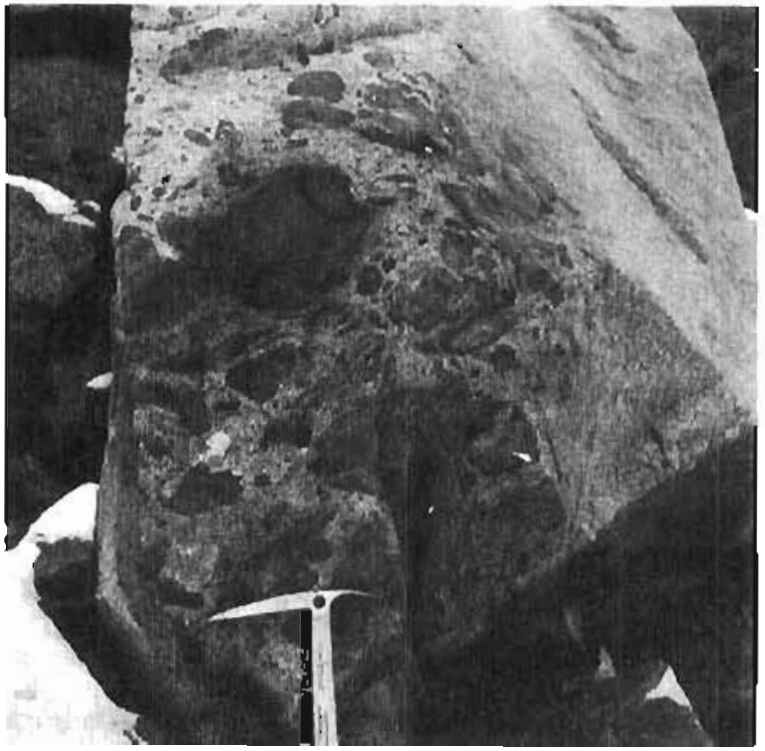

Finure 21 . Intrusive breccia formed by counlry rock ol pelitic schist contained within quartz nonzanite.

clase, biotite, and (locally) muscovice as the main constituents. This body dilfers froin the quartz monzonite (described above) by the presence of muscovile and the lack of secondary alteration.

The other mappable unit of felsic intrusive rocks is granodiorite and quartz diorite norlh of the quarl'z monzonite body between the Maclaren Clacier and Broxson Gulch. This unit corresponds 1.o the Compass Creek intrusive and the Landslide Creck granodiorite of Rose (1966). 'These rocks extend up to llir thrusi contact with the Maclaren melamorphic bell. At the contact, the quartz dioritc along the east side of the Maclaren Glacier is locally sheared and Poliated.

The contact of quartz diorite with quartz monzonite is distinct and can be mapped within a covered zone less than 20 feet wide along the west side of the East Maciaren Glacler. Al several localities, the quartz diorite is intruded by and is in fault contact witl serpentinized dunite.

Several smaller bodies of granodiorite and quartz monzonile are exposed east of Broxson Gulch. Three elongate masses of granodiorite are probably in thrust. fault contact wilh low-grade pliyllites of the Maclaren melamorphic belt norts of Aun Creck in the nortlieastern corner of the map area. These rocks are foliated near their margins and are similar to hornblende granodiorite described by Hanson (1963) in the Rainbow Mountain area east of the Delta River. Specimens JS-241A and $J S-386$ are typical. A sniall body of quartz diorite (specimen JS-51) is located north of Ann Creek near its confluence with the Delta River.

Petrographically, the granodiorite and quartz diorice ol' this unit consist of altered plagioclase, quartz, homblende, and sparse microcline (table 7). Epidote, chlorite, sericite, and opaque iron oxides are present in subordinate amounts.

The felsic intrusive rocks in the vicinity of the Broxson Gulch Thrust fault are clearly younger than the Permian volcaniclastics and andesitic flows of the upper Tetelna Complex that they intrude. However, they inust be older than both the serpentinized dunites and a perlod of major movement on the Broxson Gulch Thrust Pault. Several lines of reasoning (p. 30) argue that this movement is post-Late Cretaceous or Early 'ertiary and possibly pre-Late Oligocene. The general absence of felsic intrusive rocks in the presumed Late Oligocene and younger sediments favors this interpretation.

The quartz monzonite stock within the Maclaren metamorphic belt in the northeast comer of the map area has a preliminary $\mathrm{K}$-Ar age of approximately 30 m.y. (Turner, personal communication, 1973). It is nol known whether this age represents the 25-30 m.y. epoch of intrusion known elsewhere in Alaska (Lanphere and Reed, 1973) or the resetting of an earlier date due to movement on the Denali Frult (Stoul, 1972).

Malic and ultramafic intrusive rocks underlie a substantial portion of the study area, particularly in the eastem half of the map area along the Broxson Gulch Thrust fault syslem. Dunite and mafic gabbro pre. dominate. I'he dunite was first described in the Delta River area by Stoul (1965), who mapped the main body as far wesl as Rainy Creek. Rose $(1965,1966)$ followed liye belt along the Broxson Gulch Thrust raull as far as the East Maclaren Glacier, where only dikes of the ultramafic rock ane exposed. Kaufman (1964) reports an isolated occurrence of dunite in the headwaters of the West Fork of the Maclaren River, 10 miles further west. In all, the ultramafic belt extends at least 20 miles in an cast-west direction (fig. 2). Further east along the Denali Fault, similar duniles occur near the Canwell Glacier (Kleist, 1973) and near Mentasta Pass (Richter, 1967).

The dunite body at Rainy Creek occupies approximately 5 square miles. The oulcrops are distinctive for their reddish-brown or dun-red weathered surfaces. All but the marginal portions, however, are relatively fresh dunite (table 8) and consist of olivine (Fo86-90) and minor spinel. The exposed margins of the body are variably serpentinized, and in several localities (pl. 1) are caulted aguinst the adjacent Pennsylvanian to Permian volcanics. Thin-section examination of several specimens (table 8 ) reveal an equilibrium texture between olivine grains and abundant deformation lamallae in some grains. Serpentine, where present, is interstitial and associated with abundant secondary magnetite.

Several smaller outcrops of dunite occur as isolated outcrops along the Broxson Gulch Thrust fault. Some of these, for example on the west side of East Maclaren Glacier, are wholely serpentinized. These bodies are 
Table 8. Mades of representative mafic and ultramajic intrusive rocks north of and wilhin the Broxson Gulch Thrust faull

(The first three specimens are dunite from Rainy Creek and Broxson Guloh. The last three spoclmens are pyroxene-bearing dunito and maflc gabbro from southwest of Rainy Creek.]

\begin{tabular}{|c|c|c|c|c|c|c|}
\hline \multirow[t]{2}{*}{ Specimen No. } & B5-2-30 & JS-450 & JS-65 & $38-368$ & JS-337 & $J S \cdot 941$ \\
\hline & \multicolumn{6}{|c|}{ Modes } \\
\hline Augite & - & - & - & 10 & 48 & 55 \\
\hline Chrome spinel & 1 & - & - & - & - & . \\
\hline Magnetite & 4 & - & 1 & 1 & 1 & 3 \\
\hline Olivine & 70 & 99 & 60 & 85 & - & - \\
\hline (Fo content) & 88 & 82 & 88 & 82 & - & - \\
\hline Opaque alteration & - & - & - &. & 5 & 15 \\
\hline Orthopyroxene & - & 1 & - & - & 20 & 15 \\
\hline Plagioclase & - & - & - & - & 25 & 10 \\
\hline (An content) & $\cdot$ & - & - & - & 60 & 55 \\
\hline Serpentine & 25 & - & 39 & 4 & 1 & 1 \\
\hline
\end{tabular}

typically elongate in an east-west direction as much as 20 to 1 and are commonly bounded on their north and south sides by north-dipping thrust faults. The central portions of a few of these smaller bodies are relatively unaltered dunite, which substantiates the relationship between degree of serpentinization and the proximity to fault contacts.

Numerous bodies of gabbro and mafic gabbro are associated with the dunites. The largest of these is south of the Rainy Creek dunite east of Broxson Gulch. It is intrusive into both the Pennsylvanian dacites and andesites and the Permian Mankomen Group between Rainy Creek and Euręka Creek. Local contact metamorphism can be observed, particularly in limey beds, near well-exposed contacts.

Contacts between the gabbro and the dunite appear to be sharp over a distance of 10 to 20 feet but nowhere were the field relationships sufficiently clear to deter. mine relative ages. Both dunite and gabbro are younger than the Permian rocks they intrude, and cobbles of both are found in the Late Oligocene conglomerates that mantie the older bedrock. The almost exclusive occurrence of the dunites in the Broxson Gulch Thrust zone and their extension southeast along the erace of the Denalj Fault suggests that the thrusting and ultramanic emplacement are coeval.

No radiometric age determinations are as yet available for the hornblende and biotite-bearing felsic intrusives that are in turn intruded by dunite. Correlation of the quartz monzonite north of Ann Creek within the Maclaren metamorphic beit with the quartz monzonite east of the Maclaren Glacier implies that the dunites are younger than $65 \mathrm{~m} . \mathrm{y}$. If the Late Oligocene age assignment to the dunite conglomerates is correct, the ultramafics can be no younger than about $25 \mathrm{~m}$.y.

The only other direct age determination that bears on the age of the dunites was made by Kleist (1973). The granodiorite exposed along the south side of the Canwell Glacier (fig. 2) is intruded by dunite. An examination of the body by this writex during the summer of 1972 indicates that it is identical with the Rainy Creek dunite in its outward appearance. A biotite separate from the intruded granodionte yields a K-Ardate of $83 \mathrm{~m} . \mathrm{y}$. (Kleist, 1971).

\section{STRUCTURAL GEOLOGY}

The most important structural features in the Eureka Creck area are folds and faulis. Both are spectacularty exposed. In the following discussion, continual reference is made to the geologic map of the area (pl. 1) and to the structural sections (pl. 2).

\section{FOLDING}

Previous attempts (Rose, 1965, 1966a,b) to understand the folded nature of the layered.Paleozoic and Mesozoic sequence in the study area were unsuccessful because of an incomplete understanding of the stratigraphy. The stratigraphic relationships ascertained as part of the present study indicates that the entire sequence throush the Triassic Boulder Creek Volcanics is folded about axes that trend approximately $\mathrm{N} .76^{\circ} \mathrm{W}$. The Polds plunge at low angles $\left(<20^{\circ}\right)$ to the west.

The most notable of these folds is the Amphitheater syncline ( $p l .1$ and $\mathrm{pl}$. 2). The trace of its axial surface extends from the western margin of the rap area, near the Maclaren Glacier, east to at least Sugarloaf Mountain easl of Lower Tangle Lake---a distance of over 20 miles. Extrapolation of the folded Paxson Mountain Basalt further east suggests that the axial trace of the fold passes beneath the Tertiary and Quatemary deposits near Fielding Lake and Summit Lake. A reconnaissance mapping trip into the Amphitheater Group west of the Maclaren Glacier in the Mt. Hayes A-6 and B-6 quadrangles indicates that the $N .70^{\circ} \mathrm{W}$. trend continues until probable termination against the western extension of the Broxson Gulch Thrust Pault. Geologic field 


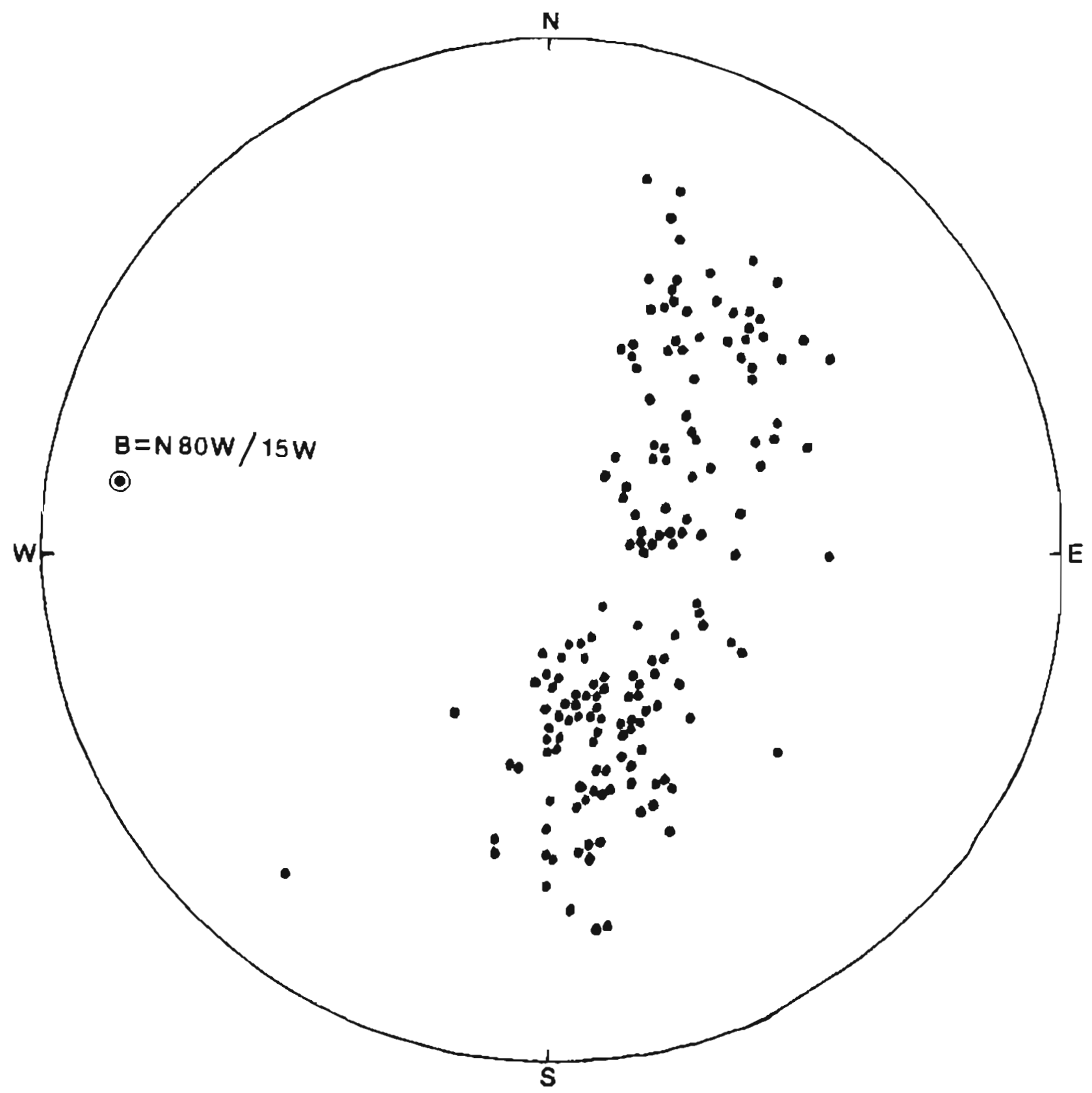

Figure 22. Poles to 167 compositional layers and bedding planes in the Amphitheater syncline.

mapping by Smith (1974c) in the Mt. Hayes A-6 quadrangle also suggests that other east-west-trending colds in the Amphitheater Group are termlnated at the structural discontinuity between Late Triassic rocks and Late Jurassic rocks.

The folded form of the Amphitheater syncline is apparent from the areal distribution of formations and their attitudes. Poles to messured attitudes on compositional layering and bedding around the syncline are represented in figure 22 . These show that the fold is approximately cylindrical over a distance of 20 miles, and has a gencle plunge to the west. A down-plunge view of the fold is readily obtained by viewing the geologic map at 15 degrees to the horizontal in a N. $80^{\circ} \mathrm{W}$. direction. The average bearing and plunge of the fold axis (fig. 22) lie in a near-vertical plane with an average axial trace taken from plate 1 . Therefore, the axial plane of the Amphitheater syncline is essentially vertical.

The north limb of the Amphitheater syncline becomes the south limb of an adjacent anticline north of 
Eureka Creck (pl. 1 and pl. 2). There, the Pennsylvanian and Permian Telelna Complex are involved in the folding. The bearing of the axial trace of the anticline is approximately N. $60^{\circ} \mathrm{W}$. and the plunge is aboul $30^{\circ}$ to $35^{\circ}$ to the west. In the Broxson Gutch area, it is quite clear that the axial Lrace of the anticline is ter. minaled against the rast.west-trending Broxson Gulch Thrust fault. The northwest- to west-lrending folds are also found in the area around Ann Creek in the north. castern comer of the map area. Soveral northwest. plunging anticlines and synclines were first mipped there by stout (1965). 'These folds are unquestionably truncated by the Broxson Gulch Thrust fault in this area.

The northwest. to west-trending set of folds is restricled lo Triassic: and older rocks. In contrast, the folds developed in the melainorphosed Jura-Cretaceous terance north of the Broxson Calch 'Thrust laull have a Lotally difterent form and orientation. Throughout the belt in the Eurcka Creek area, folds are isoclinal to subisoclinal and have their axial surfaces uniformly inclince to the north. Where measured, hinge lines plunge at. low to moderate angles to the west (pl. 1). Stuctural and petrological studies by stout (1971) reveal evidence for lwo periods of folding in the pelitic schists. An carly period is related to the Late Cre. taceous melamorphic eveni. The later period is coaxial with the nist, but differs from it by having vertical instead of inclined axial planes. This deformation may' also be related to the metamorphism, or allermatively, to either the $30 \mathrm{~m} . \mathrm{y}$. intrusive event or movement on the Denali l'ault.

These data and argumentis place definite constraints on the time of folding both in the pre-Jurassic lerrane and in the younger rocks. In the former, the evidence seems to favor a posl.Late Triassic-pre-Late Jurassic age for liye formation of the Amphithcater syncline and

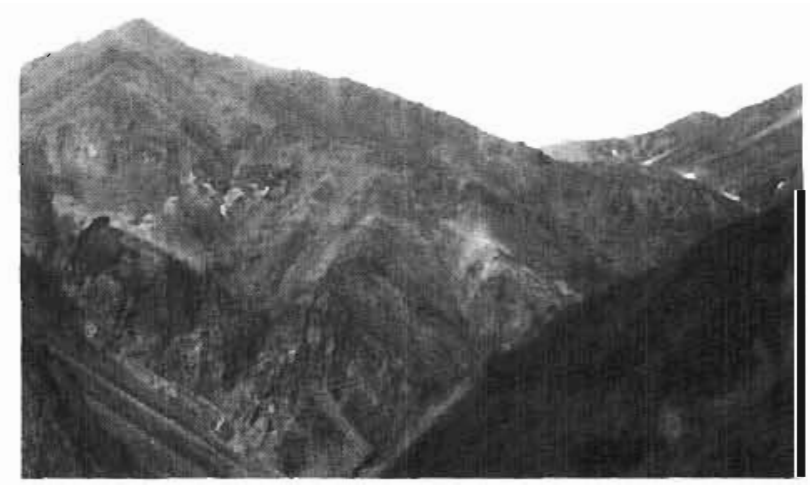

Figure. 23. The Broxson Gulch Thrust Faull (F) as viewed from the Richardson Highway near milepost 218. Note the truncalion of malic dikes $(D)$ in the underlying 'Tetelna Complex. olher folds related to it. On the other hand, the evidence clearly indicales that the folding north of the Broxson Gulch 'Thrust lault is later than their Jura-Cretaceous depositional age, and is probably contemyoraneous with the Latc Cretaceous regional metamorphism.

There is scanly evidence in the Eurcka Creck area for a folding event that postdates the Late Oligocene and younger conglomerates and coal-bearing sandstones. Gentle (but opposing) dips on Tertiary beds northwest of Fielding Lake (pl. 1) suggest an axial trace that (xtends through Dude Lake. East of the Delta River and Phelan Creek, the Tertiary beds are also folded (Bond, personal commun., 1973). Morfit (1954) and Wahrhaftig and Hickcox (1955) describe the folding in Tertiary conglomerates and coal-bearing sandstone on the north side of the Naska Range. These authors conclude that the age of folding could be as young as post.Pliocene.

\section{FAULTING}

Several laulls of probably large displacement have been mapped in the Eureka Creek ares (pl. 1). The largest of these is the Broxson Gulch 'llhrust fautt. It was first recognized in the Delta River area by Stout (1965), who followed its east-west trace as far as Rainy Creek. Rose (1965) simultancuusly recognized the fault at Broxson Guich and in fact named it after the geographic landmark. Rose (1966) extended the lrace of the fault to the East Maclaren Glacjer. 'The results of the present study show that the Broxson Gulch Thrust and related faults extend uninterrupled from the Delta River to the Maclaren Glacier, a distance of 25 miles.

Studies by Stoul (1972) indicatc that the eastern exterision of the Broxson Gulch Thrust is terminated by, or is an extension of, the Denali Fault. This juncture (fip. 2) is on the easi side of the Delta river near the Canwell Glacier. The fault may extend to the west along the 'Triassic-Jurassic boundary as fay as the Susitna River (Smith and Tumer, 1973; Smith, personal commun., 1973). The apparent truncation of the axial traces of pre-Jurassic: folds along this line (fig. 2) and the general absence of Lower and Middle Jurassic rocks here and elsewliere in Alaska (Moffil, 1954; Berg and others, 1972 ) indicates that the boundary is both a fault and an unconformity. If the fault interpretation west of the Maclaren Glacier is correct, the length of the Broxson Gulcl) Thrust fault is at least 50 miles and hence must rank as one of the major structural breaks in the Alaska Range.

The Broxson Gulch Thrust faull as herein referred actually consists of several imbricate faults that occupy a zone of deformation that ranges from several yards to 2 miles wide. The major break defines the northern margin of the zone and places the Jura-Cretaceous Maclaren melamorphic bell on lop of the Permian Tetelna Complex (fig. 23). A discontinuity in lithology 
and metamoryhic grade across the fault is apparent everywhere. Inbricate laults to the south lie wholely within the pre-Jurassic terrane.

Withoul exception, all faults within the 7,one of deformation dip al low to moderate angles to the north. In some localities (fig. 24), individual fault surfaces may even be horizontal. Commonly, a white to reddish zone (fig. 21) up to 50 feet wide marks the trace of the fault. This zone consists in some cases of finely ground, clay. nich gouge material similar to that observed along the Denali Fault (Slout and others, 1973). In other cases, the whitish zone is weatheyed, serpentinized dunite.

In contrast to the lowangle faults of the Broxson Gulch system, several large northwest-trending vertical faults exist in the map area. The most nolable of these is at Broxson Gulch, where the Broxson Gulcl Thrust fault has an apparent offset of approximately 6 miles. Rose (1966) recognized the displaced phyllites of the Maclaren belt and posiulated his Eureka fault beneath Lhe Quaternaty gravels in Broxson Gulch. The actual fault (pl. 1) is well exposed easl of Broxson Gulch, where il extends through highly deformed and thrust. caulted Permian volcanics. ILs eastern extension may correspond in part to Rose's (1965) Pioneer fault, separating the Permian Mankomen Group from the Permian Tetelna Complex near Rainy Creek.

Other northwest-trending vertical laults are postulated between Rainy Creek and Eureka Creek. The horizontal slip on these are unknown, but the vertical slip must account for several thousand feet of repeated Permian strata. Northwest-trending vertical faults are also present north of Rainy Creek in the northeast comer of the study area. Slous (1965) interpreted these as older than the north-dipping thrust faults on the basis of cross-culting relationships.

The other possibly large northwest-trending vertical faults in the area are those that bound the rish Lake Complex on the north limb of the Amphitheater syncline. These faults are not exposed, bul the degree of serpentinization and the intense shearing in the peripheral outcrops suggest at least some faull. movement along the contacts. The displacement on these faults

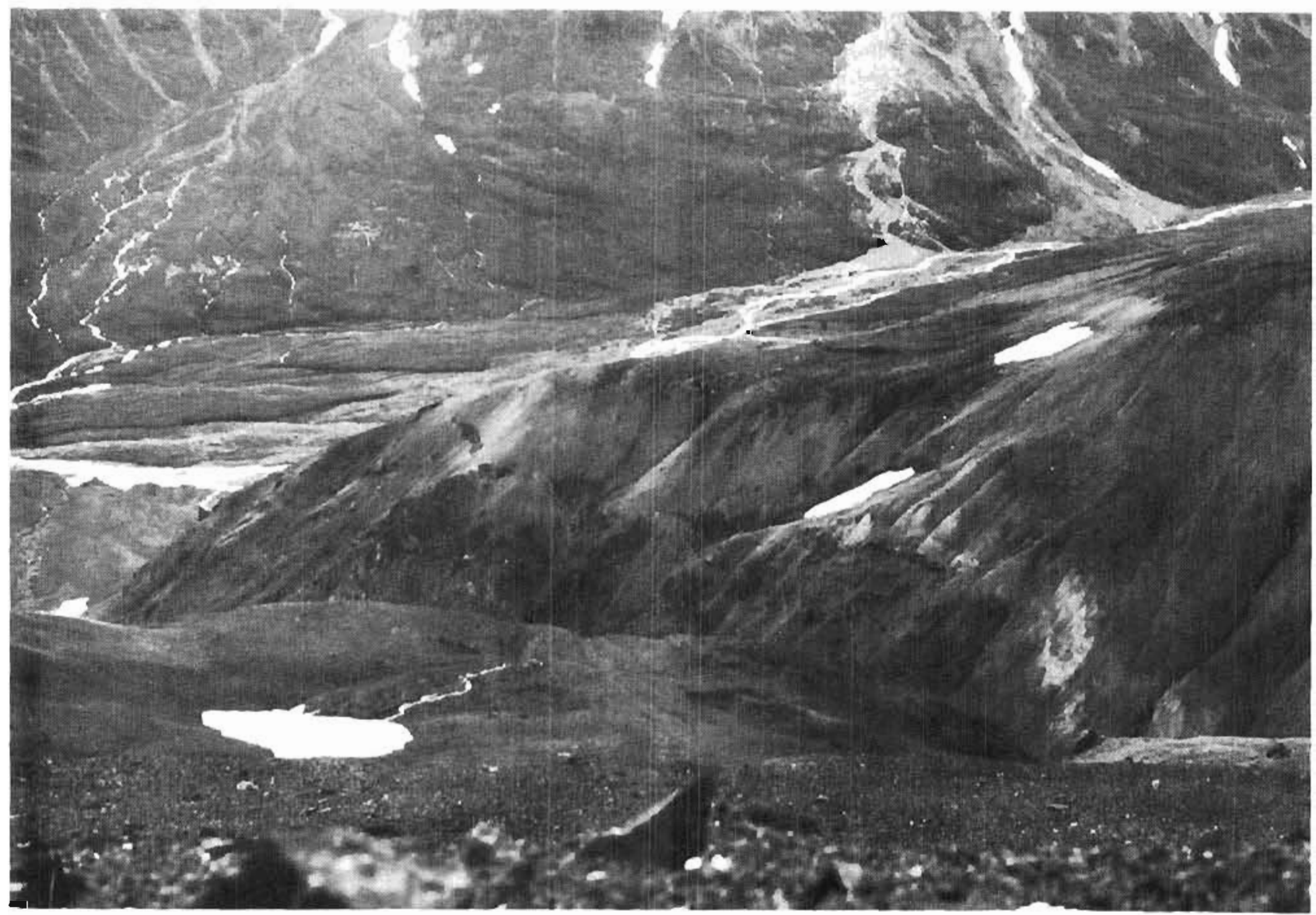

Figure 24, A near-horizontal thrust lault near Broxson Gulch which places Jura-Cretaceous phyllite (on right) on top of Permian volcanics (on left). 
is not known.

In the Amphitheater Mountains, there is evidence for only one set of faults. These appear to be vertical, and have a north-northwest trend. Apparent of sets of several hundred feet are common, and displacement of up to 1 mile is possible.

The age of Paulting in the Eureka Creek area is bracketed by the following considerations, All rocks older than Quatemary are faulted, This includes the presumed Late Oligocene conglomerates and coal-bearing sandstones. In the small drainages that disect Tertlary rocks midway between the East Maclaren Glacier and Broxson Gulch, Late Oligocene rocks are teclonically overlain by deformed quartz monzonite and Permian volcanics. The two faults that are exposed dip approximately 30 degrees to the north and appear to correlate with a similar palr of thrust faults near the terminus of the East Maclaren Glacier (pl, 1). The coalbearing beds in the underlying plate dip 70 degyees to the north. The associated conglomerates in this steeply dipping section are noteworthy because of their lack of dunite clasts. A diligent inspection of all cobble lithologies failed to reveal types characteristic of the Maclaren metamorphic belt.

One mile to the west, the relationship between the dunite conglomerates and the east-west-trending thrust faults differs. There, one thrust fault that separates gabbro from Permian volcanles is unconformably overlain by the conglomerate. This suggests the posslbility that the dunite conglomerates are younger than the Late Oligocene coal-bearing sandstones, and that thrusting took place between the times of their deposition. The absence of dunite cobbles in the older conglomerates could be interpreted to mean that the dunites had not been emplaced by Late Oligocene. However, their presence in the possibly younger conglomerates only 1 mile away and absence in the thrust-laulted older conglomerates further suggests that the thrust faults and the dunite emplacement are closely related in time.

There is independent regional evidence (Stout, 1972) that indicates the likelihood of simultaneous thrusting and dunite emplacement during the Tertiary. The age of movement on the Denali Fault that must be postulated to explain the separation of the Maclaren metamorphic belt and its possible extension in the Ruby Range, 250 miles to the east (Forbes and others, 1973; Turner and others, 1974), is younger than the regional metamorphism. It is aiso younger, at least in part, than the 30-m.y.-old quartz monzonite that is intruded into the belt. The dunite bodies along the Denall Fault at Gillett Pass, Mentasta Pass, and the Canwell Glacier are not found along the Denali Fault further west than the Delta River. Instead, the untramafic belt follows the Broxson Gulch Thrust fault in a diverted, east-west direction. These relationships can be interpreted to mean simuitaneous movement on the Broxson Gulch Thrust fauli and the Denali fault east of the Delta
River. It was at this time, perhaps after the Late Oligocene, that the dunites were emplaced into their present position.

\section{JOINTS}

The only other structural features of note in the Eureka Creek area are the well-developed joint sets in the Amphitheater Mountains. Many of these are shown on plate 1. A northwest-lrending set that dips steeply to the north is the most prominent. These joints maintain their attlude on both limbs of the Amphitheater syncline, indicating that they postdate the pre-Jurassic folding event. The other prominent joint set trends to the northeast; joints dip at moderate to steep angles, variably to the north and south. Quartz velns are rather common along this set and are locally mineyalized.

\section{ECONOMIC GEOLOGY}

Occurrences of disseminated copper and iron sulfides are common in the Eureka Creek area. In the Amphltheater Mountains, the only occurrences that justify further investigation at this time are found in quartz velns that occupy the north- to northeast-trending fracture systems described earlier. The quartz veins range in thickness from less than an inch to 12 inches, and contain chalcopyrite, bornite, malachite, azurite, and minor calcite. The chalcopyrite and bornite occur as massive pods up to 1 inch thick near a northem trib. utary of Boulder Creek and on the west side of Lower Tangle lake (pl. 1). At the latter locality, malachitecoated nuggets are scattered through the stream gravels In the drainage basin of a small cirque in that area.

The several localities shown on plate 1 are notable insofar as they are apparently restricted to the Boulder Creek Volcanics. All but one of the occurrences are located on the northern limb of the Amphitheater syncline. The exception is at Lower Tangle Lake, where the northeast-trending veins are at approximately the same stratigraphic position in the sequence but in the crest of the fold.

A linear extrapolation of this linear beit of min. eralization extends across the Maclaren River to just beyond the western boundary of the map area to the Kathleen-Margaret (KM) copper deposit. This is the richest known prospect in the area, and has apparently been active at various times since 1818 (Martin, 1920). The deposit is described by Chapman and Saunders (1964) and MacKevett (1964) as consisting of northstriking copper-bearing quarkz veins. The veins range in thickness a few inches to about 20 leet. The principal ore minerals are bornite and chalcopyrite, both commonly coated with malachite. The surrounding country rock consists of interlayered basalt (greenstone) and amygdaloidal basalt that dips to the south. There is no doubt that these rocks, too, are a part of the Boulder 
Creek Volcanics, and that they are situated on the north limb of the Amphitheater syncline.

The age of the copper mineralization is bracketed by the following considerations. The quartz veins have formed in the north-northeast-trending set of joints that have been mapped (pl. 1) over the entire area. The joints and the quartz veins cut across the folded limbs of the Amphitheater syncline with no variation in altitude that can be attributed to folding. Hence, they are younger than the pre-Late Jurassic Polding event. The dacite porphyry dikes described in earlier (p. 28) occupy the same set of joints both north and south of the Broxson Gulch Thrust fault. Although no mineralization associated with the dikes has been observed, they may have an origin common with the copperbearing quartz veins. If so, the mineralization may be Tertiary and perhaps as young as Late Oligocene.

Several nickel-copper occurrences are known in the Eureka Creek area. All of them are assoclated with the Tertiary ultramafic rocks in the vicinity of the Broxson Gulch Thrust fault. The localities visited by this writer are described in some detail by Rose $(1965,1966)$. The most notable of these is the Pioneer claim on the upper part of Rainy Creek (pl. 1). There, a light-colored gabbro porphyry contained enough disseminated chalcopyrite to justify a preliminary drilling operation in the summer of 1974 (Mark-Anthony, personal commun., 1973). This deposit, like the others in the area associated with the ultramafic belt and the low-angle faulting, are Tertiary.

\section{REFERENCES CITED}

Andreason, G.E., Grantz, A., Zietz, I., and Barnes, D.F., 1964, Geologic interpretation of magnetic and gravity data in the Copper River Basin: U.S. Geol. Survey Prof. Paper 316-H, p. 185-153.

Berg, H.C., Jones, D.L., and Richter, D.H., 1972 , Gravina-Nutzotin belt--tectonic significance of an upper Mesozoic sedimentary and volcanic sequence in southern and southeastern Alaska: U.S. Geol Survey Prof. Paper 800-D, p. D1-D24.

Bond, G.C., 1970, Early Permian sedimentation and paleogeography in east-central Alaska Range and regional implications: Am. Assoc. Petrol. Geol. Bull., v. 54, no. 12 , p. 2470-2471.

Brooks, A.H., and others, 1918, Mineral regources of Alaska: U.S. Geol. Survey Bull. 662, p. 43-44.

Capps, S.R., 1916, The Chisana-White Rivar districh, Alaska: U.S. Geol. Survey Bull. 630.

Chapin, $T ., 1918$, The Nelchina-Susitna region: U.S. Geol, Survay Bull. 668.

Chapman, R.M., and Saunders, R.H., 1954, The Kathleen-Margaret (KM) copper prospect on the upper Maclaren River, Alaska: U.S. Geol. Survey Círc. $332,5 \mathrm{p}$.

Clark, A.L., Clark, S.H.B., and Hawley, C.C., 1972, Significance of Upper Paleozoic oceanic crust in the Upper Chulitna district, west-central Alaska Range: U.S. Geol. Survey Prof, Paper 880-C, p. C95-C101.
Forbes, R.B., Turner, D.L., Stout, J.H., and Smith, T.E., 1973, Cenozoic offset along the Denali Fault, Alaska [abs.] : Trans. Amer. Geophys. Union, v. 54, o. 495.

Force, Eric R, 1973, Permian-Triassic contact relations in circum-pacific geosynclines: Pacific Geology, v. 6, p. 19-23.

Hanson, L.G., 1965, Bedrock geology of the Rainbow Mountain area, Alaska Range, Alaska: Alaska Div. Mines and Minerals Geol. Rept. 2, 82 p.

Kaufman, M.A., 1964, Goology and mineral deposits of the Denali-Maclaren River area, AJaska: Alaska Div. Mines and Minerals Geol. Rept. A, p. 1-15.

Kleist, J.R, 1971, The Denali Fault in the Canwell Glacier area, east-central Alaska Range: M.S. thesis, Univ. of Wisconsin, $111 \mathrm{p}$.

-1.1972, Kink bands along the Denali Fault, Alaska: Geol. Soc. Amer. Bull. v. 83, p. 3487-8490.

Lanphere, M.A., and Reed, B.L., 1973, Timiug of Mesozoic and Cenozoic plutonic events in circumpacific North America: Geol, Soc. Amer. Bult., v. 84, p. 3773-3782.

MacKevelt, E.M., 1964, Ore controls at the KathleenMargaret (Moclaren River) copper deposit, Alaska: U.8. Geol. Survey Prof. Paper 501-C, p. C117-C120.

MacKevett, E.M., Ir., 1969, Geologic map of the McCarthy C.4 quadrangle, Alaska: U.S. Geol. Survey Geol. Quad, Map GQ-844.

Martin, G.C., 1920, The Alaskan mining industry in 1918: U.S. Geol. Survey Bull. 712, p. 20.

Martin, G.C., 1926, The Mesozoic stratigraphy of Alaska: U.S. Gool. Survey Bull. 776.

Mendenhall, W.C., 1900, A reconnaissance from Resurrection Bay to Tanana River, Alaska, in 1898: Twentieth Ann. Rept., U.S. Geol. Surrey, pt. ?, p. $271 \cdot 340$.

3905, Geology of the central Copper River region, Alaska: U.S. Geol. Survey Prof. Paper 41.

Mendenhall, W.C., and Schrader, F.C., 1908, Mineral resources of the Mt. Wrangell district, Alaska: U.S. Geol. Survey Prof. Paper 15.

Moffit, F.H., 1912, Headwater regions of Gulkana and Susitna River, Alaska, with accounts of the Valdez Creek and Chistochina placer districts: U.S. Geol. Survey Bull. $498,82 \mathrm{p}$.

- _, 1918, Geology of the Nutzotin Mountains, with a section on the igneous rocks by R.G. Wayland: U.S. Geol. Survey Bull. 938, p. 108-174.

, 1954, Geology of the eastern part of the Alaska Range and adjacent area: U.S. Geol. Survey Bull. 989-C, p. 65-218.

Muller, J.E., 1967, Kluane Lake maparea, Yukon Territory: Geol, Survey Am. Mem. 340, $137 \mathrm{p}$.

Petocz, R.G., 1970, Biostratigraphy and Lower Permian Fusulinidae of the Upper Deita River area, Eastcentral Alaska Range: Geol. Soc. Amer. Spec, Paper $130,94 \mathrm{p}$.

Quick, James E., 1974, Coexisting chromian spinel and olivine as a geothermometer: M.A. thesis, Univ. of Minnesota, $27 \mathrm{p}$.

Reed, B.L., and Lanphere, M. A., 1970, Plutonic belts of the central and soutbern Alaska Range and Alaska Peninsula [abs,]: Amer. Assoc, Petrol. Geol. Bull, v. 54, p. 2502 . 
1973, Alaska-Aleutian Range batholith: Geochronology, chemistry, and relation to circum.pacific plutonism: Geol. Soc. Amer. Bull., v. 84, P. 26882610.

Richter, D.H., 1966, Geology of the Slana district, southcentral Alaska: Alaska Div, of Mines and Minexals Geol, Rept. 21, 51 p.

, 1967, Geology of the upper Slana-Mentasta Pass area: Alaska Div. Mines and Minerals Geol. Rept. 30, $25 \mathrm{p}$.

Richter, D.H., and Jones, D.L., 1970, Structure and stratigraphy of oastern Alaska Range, Alaska: Am. Assoc, Petrol. Geol, Bull., v-54, no, 12, p. 25022503 .

-1972, Reconnaissance geologic map and sections of the Nabesna A-2 quadrangle, Alaska: U.S. Geol. Survey Misc. Geol. Inv, Map I-749.

Richter, D.H., and Matson, N.A., Jr., 1969, Mineral occurrence in eastern Alaska Range described: U.S. Geol, Surv. Prof. Paper 660-A, p. A51.

Rose, A.W., 1965, Geology and mineral deposits of the Painy Creek area, Mt. Hayes quadrangle, Alaska: Alaska Div, Mines and Minerals Geol. Rept. 14, 61 p.

- 1966a, Geological and geochemical investigations in the Eureka Creek and Rainy Creek areas, Mt. Hayes quadrangle, Alaska: Alaska Div. Mines and Minerals Geol. Rept. 20, 36 p.

- 1966b, Geology of part of the Amphitheater Mountains, Mt. Hayes quadrangle, Alaska: Alaska Div, Mines and Minerals Geol. Rept. 19, 12 p.

Rose, A.W., and Saunders, R.H., 1965, Geology and geochemical investigations near Paxson, northern Copper River Basin, Alaska: Alaska Div. Mines and Minerals Geol. Rept. 13, 18 p.

Ross, C.P., 1938, Valdez Creek mining district: U.S. Geol. Survey Bull. 849-H, p. 425-468.

Rowett, C.L., 1969 , Upper Paleozoic stratigraphy and corals trom east-central Alaska Range, Alaska: Arctic Inst. North America Tech. Paper 23, $120 \mathrm{p}$.

- 1971, Reconnaissance biostratigraphy of the Lower Permian in the Slana area, eastern Alaska Range, Alaska: Pacific Geology, v. 3, p. 31-44.

Rowett, C.L., and Timmer, R., 1973, Lophophyllidid, Hapsiphyllid and Polycoelid corals of Pennsylvanian age from the east-central Alaska Range: Pacific Geology, v. 6, p. 1-18.

Smith, T.E., 1970a, Results of geochemical sampling in the western Clearwater Mountains, Alaska: U.S. Geol. Survey open file report, $249 \mathrm{p}$.

1970b, Inverted metamorphic zonation in the northern Clearwater Mountains, Alaska [abs.], in Geological Survey Research 1970: U.S. Geol. Survey Prof. Paper 700-A, p. A47-A48. , 1971, Geology, economic geochemistry, and placer gold resources of the western Clearwater Mountains, east-central Alaska: Ph. D. thesis, Univ. of Nevada.
, 1974a, Regional geology of the Susitna-Maclaren

River area, central Alaska: in Alaska Div. Geol. and Geophys. Surveys Annual Rept. 1973, p. 3-6.

- Geology of the western Clearwater Mountains, central Alaska: Alaska Div. Geol. and Geophys. Surveys Geol. Rept. (in process).

-. Geologic map of the Mt. Hayes A-6 quadrangle: Alaska Div. Geol. and Geophys. Surveys (in process).

Smith, T.E., and Lanphere, M.A., 1971, Age of the sedimentation, plutonism and regional metamorphism in the Clearwater Mountains remion, central Alaska: Isochron/West, no. 2, p. 17-20.

Smith, T.E., and Turner, D.L., 1973, Geochronology of the Maclaren metamorphic belt, south-central Alaska: A progress report: Isochron/West, no. 7, p. 21-25.

, 1974, Maclaren metamorphic belt of central Alaska [abs.] : Geol. Soc. Amer. Cordilleran Meeting.

Stout, J.H., 1965, Bedrock geology between Rainy Creek and the Denali Fault, eastern Alaska Range, Alaska: Unpub. M.S. thesis, Univ. of Alaska, 75 p.

- 1972, Regional metamorphism and structure along the Denali Fault, east-central Alaska Range [abs.]: Geol. Soc. Amer. Annual meetiug, Minneapolis.

, Progressive metamorphism and phase chemistry of pelitic schists and amphiboltes from the Maclaren metamorphic belt, Alaska (in process).

Stout, J.H., Brady, J.B., and Callender, J., 1972 , Quaternary movement on the Denali Fault in the Delta River area, Alaska [abs.]: Geol. Soc. Amer. Abstracts with Programs, Cordilleran Section, v. 4, p. 243.

Stout, J.H., Brady, J.B., Weber, F., and Page, R.B., 1973, Evidenco for Quaternary movement on the McKinley Strand of the Denali Fault in the Delta River area, Alaska: Gool. Soc. Amer. Bull. v. 84, p. 939.948 .

Surdam, R.C., 1968, Electron microprobe study of prehnite and pumpellyite from the Karmutisen Group, Vancouver Island, B.C.: Amer. Mineral. 54, p. 256266.

Turner, D.L., Smith, T.E., and Forbes, R.B., 1874 , Geochronology of offset along the Denali Fault system in Alaska [abs.]: Geol. Soc. Amer, Cordilleran meeting.

Wahrhaftig, C., and Hickox, C.A., 1955, Geology and coal deposits, Jarvis Creek coal field, Alaska: U.S. Geol. Surv. Bull. 989-G, p. 353-367.

Wahrhaftig, C., Wolfe, J.A., Leopold, E.B., and Lanphere, M.A., 1969, The coal-bearing group in the Nenana coal field, Alaska: U.S. Geol. Survey Bull. 1274-D, $30 \mathrm{p}$.

Wolfe, J.A., 1966, Tertiary plants from the Cook Inlet region, Alaska: U.S. Geol. Survey Prof. Paper 398-B, p. B1-B32.

1972, Interpretation of Algskan Tertiary floras: in Floristics and paleofloristics of Asia and eastern North America, ed. Graham, A., Elsevier, p. 201-233. 